\title{
İşletmelerin Marka Değerleri Ille Performanslarının Karşılaştırmalı Analizi: Otomotiv Sektöründe Faaliyette Bulunan Markalara Yönelik Bir Araştırma
}

\author{
Comparative Analysis of Brand Values and Performances of Businesses: A Research For Brands Activity In The \\ Automotive Industry
}

\author{
V. Özlem Akgün ${ }^{* 1}$ (iD \\ ${ }^{1}$ Department of International Trade and Finance, Selçuk University, Konya, Turkey
}

Received: 13.08 .2021

Accepted: 25.09 .2021

This article was checked by intihal.net

\section{Öz}

Başarılı ve güçlü bir marka yaratmak, markayı sürdürülebilir kılmak, yüksek bir marka değeri oluşturmak ve bu değeri korumak, müşterinin istek ve ihtiyaçlarını doğru anlamak, bu ihtiyaçlara yönelik doğru ürünleri sunmak, yenilikçi ürünleri takip etmek artık işletmeler için birer istekten öte ihtiyaç halini almıştır. Bugünün pazarlama ortamında marka değerlemede farklı yöntemlerden faydalanılmaktadır. Özellikle danışmanlık şirketleri farklı ölçütlerden yararlanarak şirketlerin marka değerlerini hesaplamaya yönelik önemli çalışmalar yürütmektedir. Yapılan bu çalışmanın amacı; Brand Finance Türkiye 100 sıralamasında bulunan otomotiv sektörü işletmelerinin performanslarının, Entropi Temelli TOPSis yöntemi ile değerlendirilerek ilgili işletmelerin Brand Finance Türkiye 100 sıralamaları ile performans sıralamalarının karşılaştırmalı olarak analiz edilmesidir. Bu kapsamda, öncelikle marka, marka değeri ve marka değerleme yöntemlerine yönelik bilgi verilmiş sonrasında ise çalışmanın uygulama kısmında 2018, 2019 ve 2020 yıllarında Brand Finance Türkiye 100 sıralamasına giren otomotiv sektörü kuruluşlarının marka değeri sıralaması ile performans sıralamaları karşııklı olarak analiz edilmiştir. Marka değeri sıralamaları için yıllık olarak yayınlanan Brand Finance Türkiye 100 raporlarından yararlanılmıştır. Performans sıralamaları için aynı işletmelerden Borsa İstanbul'da işlem görenlerin ilgili tablolarından elde edilen veriler, karar kriteri olarak kullanılmıştır. Çalışma sonucunda; araştırma döneminde, marka değeri en yüksek olan işletmelerin, performanslarının da en yüksek olduğu bulgusu elde edilmiştir.

Anahtar Kelimeler: Marka Değeri, Marka Değerleme Yöntemleri, TOPSis, ENTROPI, Otomotiv Sektörü

\section{Abstract}

Creating a successful and strong brand, making the brand sustainable, creating and maintaining a high brand value, understanding the wishes and needs of the customers correctly, offering the right products for these needs, and following innovative products have now become a necessity rather than a request for businesses. In today's marketing environment, different methods are used in brand valuation. Especially consultancy companies carry out important studies to calculate the brand values of companies by using different criteria. The aim of this study is to evaluate the performances of the automotive sector companies in the Brand Finance Turkey 100 ranking with the Entropy-Based TOPSIS method and to analyze the Brand Finance Turkey 100 rankings of the related companies and their performance rankings comparatively. In this context, first of all, information about the brand, brand equity and brand valuation methods was given, and then, in the application part of the study, the brand value ranking and performance rankings of the automotive sector organizations that listed in the Brand Finance Turkey 100 ranking in 2018, 2019 and 2020 were analyzed mutually. Brand Finance Turkey 100 reports published annually were used for brand value rankings. For the performance rankings, the data obtained from the relevant tables of the same companies traded on Borsa Istanbul were used as decision criteria. The study concluded that the companies with the highest brand value had the highest performance during the research period.

Keywords: Brand Equity, Brand Valuation Methods, TOPSIS, ENTROPY, Automotive Sector

Akgün, Ö. (2021). İ̧̧letmelerin Marka Değerleri ile Performanslarının Karşılaştırmalı Analizi: Otomotiv Sektöründe Faaliyette Bulunan Markalara Yönelik Bir Araştırma. Journal of Academic Value Studies, 7(3), 243-267. http://dx.doi.org/10.29228/javs.52335

\footnotetext{
${ }^{*}$ E-mail address: ozlemakgun@selcuk.edu.tr
} 


\section{Giriş}

Marka, bir ürünü diğer ürünlerden ayırt etmeye yarayan; her türlü, isim, resim, şekil, logo, tasarım veya benzeri niteliklerdir. Markalar; genellikle bir şirketin, gelirinin ve rekabet avantajının önemli bir kaynağı olarak kabul edilmektedir (Barwise vd., 1990). Bir ürünü diğer ürünlerden farklı kılmanın en önemli yollarından bir tanesi olarak ele alınan marka kavramı, mal veya hizmeti benzersiz kılan nitelikler sunarak müşterilerin ürüne yönelik beklentilerini karşılamaya hizmet etmektedir. Markalar, şirketlerin en değerli varlıkları arasında yer almaktadır. Mevcut küresel rekabet pazarında, tüketicilerin çok sayıda ürün alternatifi arasından seçim yapabilmesi artık hiç olmadığı kadar zordur. Bu sebeple karar verme sürecinde ve sürdürülebilir rekabet avantajı sağlama bağlamında, markanın oynadığı rol, geçmişe kıyasla çok daha kritiktir. Bununla birlikte güçlü bir marka değeri oluşturmak ve bu yolla rakiplerden sıyrılarak iyi bir pazar konumu elde etmek, etkili marka stratejileri yaratma bağlamında pazarlama yöneticilerine önemli fırsatlar sunmaktadır.

Marka değerlemesi ise, marka satın alımlarında işletmelerin rasyonel biçimde karar vermeleri bağlamında stratejik bir araç niteliğindedir. Marka değerlemesi sayesinde, satın alınması düşünülen markanın gerçek değeri ortaya koyulabilmekte ve bu yolla da işletmenin, marka için ödemeye istekli olduğu bedelin uygun olup olmadığı tespit edilebilmektedir (Kara, 2019: 228). Marka değerlemesi konusunda farklı yöntemlerden faydalanılmaktadır. Pazar temelli yaklaşım, maliyet temelli yaklaşım, gelire dayalı yaklaşım ya da formüler yaklaşım en sık kullanılan yöntemler arasında yer almaktadır. Özellikle son yıllarda, markalara yönelik değer tahmini yürütmek amacıyla bağımsız araştırma şirketleri tarafından yayınlanan raporlara, sıkıkla başvurulmaktadır. Maddi olmayan duran varlıkların öneminin artması, bu durumun en önemli gerekçelerinden birisini oluşturmaktadır. Brand Finance, InterBrand, Young\&Rubicam gibi bazı danışmanlık şirketleri, belirli sektörler, belli faaliyet alanları, belli ülkeler ya da küresel bazlı işletmeler için en güçıü ve en değerli markaların tespitine yönelik birtakım listeler sunmaktadır. Farklı amaçlara yönelik olarak hazırlanan bu listelerin, tüketiciler, yatırımcılar, paydaşlar ya da diğer ilgili taraflarca yoğun ilgi gördüğü rahatılıkla ifade edilebilmektedir.

Yapılan bu çalışmada kavramsal çerçeve kapsamında öncelikle; marka, marka değeri ve marka değerleme yöntemlerine yönelik teorik bilgiler aktarılmış, metodoloji kısmında ise Brand Finance Türkiye 100 sıralamasında bulunan otomotiv sektörü işletmelerinin performansları, Entropi Temelli TOPSis yöntemi ile değerlendirilmiş, ilgili işletmelerin Brand Finance Türkiye 100 sıralamaları ile performans sıralamaları karşılaştırmalı olarak analiz edilmiş ve bu analizin bulgularına yer verilmiştir.

\section{Kavramsal Çerçeve}

\subsection{Marka, Marka Değeri ve Marka Değerleme Yöntemlerine Kısa Bir Bakış}

Amerikan Pazarlama Derneğine göre marka, satııının mal ya da hizmetini öteki satıcılarınkinden farklı biçimde tanımlayan bir isim, terim, tasarım, sembol veya diğer herhangi bir niteliktir. Bununla birlikte ISO bu tanıma, paydaşların zihninde farklı imajlar ve çağrışımlar oluşturmayı ve böylece ekonomik fayda/değer üretmeyi hedefleyen maddi olmayan bir varlık olduğunu eklemektedir (AMA, 2021). Marka, bir ürünün, işletmenin veya bireyin onu deneyimleyenler tarafından algılanma şeklidir. Marka, bir başka tanıma göre; bir isim veya logodan çok daha fazlası, bu varlıkların uyandırdığı tanınabilir duygular veya algılardır (Lischer, 2021). Marka, bir varlığın (kişi, kuruluş, şirket, iş birimi, şehir, ülke vb.) tanınmayı amaçladığı tüm ifadelerin toplamıdır ve kalitenin ve temsil ettiği değerlerin simgesi olarak tüketici karar verme sürecinde oldukça önemlidir (Hertioga ve Christenses, 2021; Svetlik ve Vavrecka, 2016: 287). Bugünün pazarlama dünyasında, rekabetin hızla artması, çok sayıda yeni ürünün piyasaya sunulması, bilinçli müşteri sayısındaki hızlı yükselme, markaların sosyal statü simgesi haline gelmesi, sürekli değişen müşteri istek ve beklentileri gibi pek çok faktöre bağlı olarak marka kavramı uygulanacak pazarlama stratejileri bağlamında çok daha önemli bir rol üstlenmektedir. Sürekli değişen rekabet ortamında marka değerini korumak ise bugünün pazarlama ortamında, hiç olmadığı kadar zordur.

İlgili literatür incelendiğinde; marka değerinin, "brand equity" ve "brand value" gibi farklı kavramlarla yer aldığı görülmektedir (Şahin vd. 2018: 325). Brand equity kavramı, esasında marka sermayesi şeklinde ifade edilen ve tüketicinin bildiği, güvenmiş olduğu bir marka için öteki markalara kıyasla daha çok bedel ödemeyi kabul ettiği pozitif farkı ifade etmekte iken; "brand value" olarak tanımlanan asıl marka değeri, marka sermayesinin bir sonucu olarak, markalı ürün satışından kaynaklanan, markanın işletmede olması gereken değerine karşılık gelmektedir (Başçı, 2009: 21'den aktaran Şahin vd. 2018: 325). Simon ve Sullivan (1993: 29) marka denkliğini, markalı ürünlerde, markasız ürünlerin satışından kaynaklanacak nakit akışlarının üzerinde tahakkuk eden nakit akışları olarak tanımlamıştır. Kucharska'ya göre (2016: 139) ise marka değeri; belirli bir süre içinde, benimsenen stratejilerin verimliliğini ve etkinliğini ölçmenin nesnel bir yolunu oluşturan, pazarlama faaliyetlerinin tam ve nihai sonucudur. Esasında her iki tanımlama da 
maddi olmayan duran varlığın potansiyeline vurgu yapmaktadır (Kucharska vd., 2018: 770). Marka değeri, bir mal veya hizmet tarafından sağlanan değere eklenen veya ondan çıkarılan bir markanın adı ve sembolü ile bağlantılı bir varlık veya yükümlülükleri toplamıdır. En önemli değer bileşenleri ise, marka bilinirliği, marka sadakati, algılanan kalite ve marka çağrışımlarını içermektedir (Aaker, 2003). Keller (1993) ise markayı tüketici bakış açısından algılamaktadır ve marka değeri unsurları ile ilgili olarak marka imajı ve marka bilinirliğine vurgu yapmaktadır. Bu iki bileşen ise Aaker'in yapmış olduğu tanımlamadan farklı olarak tüketici temelli marka denkliğini vurgulamaktadır (Alemdar ve Dirik, 2016: 823). Bir başka ifade ile, Keller markayı tutarlı bir biçimde tüketicinin bakış açısından algılamaktadır. Keller'in yapmış olduğu tanım, hem tüketicilerin hedef markanın olumlu çağrışımlar yoluyla pazarlanmasına verdiği tepkiye hem de benzer ürünlere kıyasla farklı bir imaja odaklanmaktadır (Gajanova vd., 2021: 153). Marka değeri, markanın itibarı ile ilgili kazançların bugünkü değerini ifade etmektedir (Brand Finance, 2021). Lassar vd. (1995: 11) marka değerine, finansal ve müşteri temelli olmak üzere iki farklı perspektiften yaklaşmayı önermektedir. Marka değerinin, finansal perspektifi, finansal varlıkların değerine dayanmaktadır. Öte yandan, müşteri temelli bir marka değeri beş temel boyut dahilinde belirlenmektedir. Bu boyutlar; performans, değer, sosyal imaj, güvenilirlik ve bağlııktır. Marka değeri, bir markanın ticari faaliyetlerini yöneticilerin, bir şirketin hedeflerine ulaşmasına izin verecek şekilde yürütme yeteneğini göstermektedir (Srivastava vd. 1998: 168). Bir üreticinin sunduğu marka değeri, tüketicilere duygusal, ticari müşterilere ise rasyonel değer sağlamaktadır. Aynı zamanda bu değer hem tüketicilere hem de ticari müşterilere sağladığı değerin önemli bir unsuru olarak üreticinin operasyonel verimliliğini de yansıtmaktadır (Parment, 2008: 250). Baydaş (2011: 131) genel itibariyle marka değerinin, rekabet gücü sağlayacak biçimde markanın pazardaki gücünü yansıttığını ve bu bağlamda önemli bir konu olarak değerlendirildiğini ifade etmektedir.

Marka değerleme yöntemlerine ilişkin yaklaşımlar özellikle, işletmelerin bilançolarında maddi olmayan duran varlıkların artan önemi nedeniyle çok daha fazla üzerinde durulan güncel bir konudur (Skalicky vd., 2021: 160). Marka değerlemesinin başlıca faydaları (Wood, 1995); hissedarların fonlarına gerçekçi bir görünüm sağlaması, benzer pazarlarda faaliyet gösteren işletmeleri karşılaştırmak için mantıklı bir temel sağlaması, portföyde yer alan markaları karşılaştırmak için platform sağlaması, marka yönetimi için gelecek planlamasına yardımcı olması, pazarlama kaynaklarının buna göre tahsis edilmesi, birleşme ve devralma kararlarının alınmasına fayda sağlaması, markanın değerini net bir biçimde ortaya koyarak fon toplamaya yardımcı olması şeklinde özetlenebilmektedir. Marka değerlemesi yöntemleri esasında çok eski bir geçmişe sahip değildir. Marka değerlemesi, özellikle 1980'lerde birçok İngiliz şirketin diğer rakip işletmeleri devralmasıyla başlamıştır (Mishra, 2016: 43). Marka değerini ölçmek için genellikle dört temel yöntemden faydalanılmaktadır (Yazdanparast ve Bayar 2021; Cravens ve Guilding, 1999; Seetharaman vd., 2001; Nam, 2010):

(a)Pazar temelli yaklaşım; bir markanın satılabileceği değeri ölçmektedir. Pazar temelli yaklaşımda, benzer markaların dahil olduğu işlemler ve işlem fiyatlarının ait olduğu veriler incelenmektedir. Bu yöntemin zorluğu, gerçek bir pazarı olmayan markalara pazar değeri atama zorluğu yaşanabilmesidir. Karşılaştırabilir işlem sayısı uygun olduğunda, piyasa koşullarında muvazaasız işlemlerde ve işlem uygun ve belli bir zamanda etkilendiyse pazar temelli yaklaşımın kullanımı daha uygun olmaktadır.

(b) Maliyet temelli yaklaşım; Ar-Ge çalışmaları, tutundurma faaliyetleri ve kademeli iyileştirme aşamaları aracılığıyla bir marka yaratmayla ilişkili maliyetleri incelemektedir. Bir başka deyişle; maliyet temelli yaklaşımda, marka geliştirme sürecindeki bazı ya da tüm marka geliştirme faaliyetlerinin maliyetleri aracılığıyla marka değeri hesaplanmaktadır. Doğrudan markaya atfedilemeyen ancak markayı destekleyen maliyetleri belirlemenin genellikle zor olması, bu yöntemin önemli bir dezavantajını oluşturmaktadır. Bununla birlikte iyi bir değer göstergesi olmaması, marka yönetiminin sağlamış olduğu katma değeri kapsamaması, marka uzunca bir süredir piyasadaysa, gerçekleşmiş maliyetlerin tespitinin zorluğu da diğer dezavantajlar arasındadır.

(c) Gelire dayalı yaklaşım, rekabet avantajlarının kritik rolünü göz ardı ederken, alternatifler veya telif ücretleri üzerindeki fiyat priminden gelecekteki gelirlere dayalı olarak markanın potansiyelini göz önüne almaktadır. Bu yöntemde, markanın tahmin edilen kalan kullanım ömrü süresince markayla ilgili gelecek, gelir, kar ve nakit akımlarının tespit edilmesi ve bu verilerin şimdiki zamana indirgenmeleri gerekmektedir.

(d) Formüler yaklaşım; bahsedilen üç yöntemden daha geniştir, çünkü bu yöntemde markanın değer yaratma yeteneği ile bütünleşik tüm faktörlerin eksiksiz olarak değerlendirilmesi için maliyet ve pazar temelli yaklaşımlardan elde edilen rekabet avantajları, gelir temelli yaklaşımdan gelecek gelirle birleştirilmektedir. Formüler yaklaşımın örnekleri arasında; Aaker'in on marka değeri sıralaması, Financial Word dergisinde yer alan sıralamalar, Kantar Millward Brown'dan BrandZ sıralaması, InterBrand sıralamaları, BrandFinance sıralamaları sayılabilmektedir. 
Bugün pek çok danışmanlık şirketi, marka değerini ölçmek için kendi özel yöntemlerinden faydalanmaktadır. Formüler yaklaşım kapsamında değerlendirilen bu araştırma şirketleri, marka değerleme yöntemlerinde farklı ölçeklerden yararlanmaktadır. Örneğin; InterBrand, pazar, istikrar, marka liderliği, trend, marka desteği, çeşitlendirme; Young\&Rubicam, bilgi, saygı, ilgi, farklılaştırma, AC Nielsen Winnig Brands, farkındalık, göz önüne alma, ürüne ait üç nitelik; BrandFinance, farkındalık, aşinalık, göz önüne alma, tercih-yeğleme, memnuniyet tavsiye, gibi marka gücü boyutlarını ele almaktadır (Chernatony, 2010'dan aktaran; Kara, 2019: 230).

Brand Finance tarafından yapılan araştırma raporu sonucuna göre, 2021 yılı küresel markalar sıralaması Şekil 1'de gösterildiği gibidir. 2021 yılına ait raporlardaki sıralamalar, 2020 yılı verileri esas alınarak gerçekleştirilmiştir. Bu sebeple, 2021 yılı sıralamaları, 2020 yılındaki marka değeri sırlamalarını göstermektedir.

\section{Şekil 1. 2021 Yılı Küresel 500 Marka Sıralaması}

\begin{tabular}{|c|c|c|c|c|c|c|}
\hline 2021 & 2020 & Logo & Name & Country & 2021 & 2020 \\
\hline $1 \wedge$ & 3 & 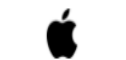 & Apple & 틀 & $\$ 263,375 M$ & $\$ 140,524 M$ \\
\hline $2 v$ & 1 & amazon & Amazon & 些 & $\$ 254,188 \mathrm{M}$ & $\$ 220,791 M$ \\
\hline $3 v$ & 2 & Google & Google & 些 & $\$ 191,215 M$ & $\$ 188,512 M$ \\
\hline $4=$ & 4 & Hilicrosott & Microsoft & 些 & $\$ 140,435 M$ & $\$ 117,072 M$ \\
\hline $5=$ & 5 & snmsure & Samsung Group & : & $\$ 102,623 \mathrm{M}$ & $\$ 94,494 M$ \\
\hline $6 \wedge$ & 8 & Walmart 次 & Walmart & 些 & $\$ 93,185 \mathrm{M}$ & $\$ 77,520 \mathrm{M}$ \\
\hline $7=$ & 7 & facebook & Facebook & 些 & $\$ 81,476 \mathrm{M}$ & $\$ 79,804 M$ \\
\hline $8 v$ & 6 & $=0 .$. & ICBC & E & $\$ 72,788 \mathrm{M}$ & $\$ 80,791 \mathrm{M}$ \\
\hline $9 \wedge$ & 12 & verizon & Verizon & 些 & $\$ 68,890 M$ & $\$ 63,692 \mathrm{M}$ \\
\hline $10 \wedge$ & 19 & 8 & WeChat & - & $\$ 67,902 M$ & $\$ 54,146 \mathrm{M}$ \\
\hline $11 \wedge$ & 13 & Comang & China Construction Bank & : & $\$ 59,649 M$ & $\$ 62,602 \mathrm{M}$ \\
\hline $12 \wedge$ & 15 & - & Toyota & - & $\$ 59,479 M$ & $\$ 58,076 \mathrm{M}$ \\
\hline
\end{tabular}

Kaynak: www.brandirectory.com

Global-500, dünyanın en değerli markaları sıralamasına göre 263,375 milyar dolar marka değeri ile Apple dünyanın en değerli markası seçilmiştir. Amazon, 254,188 milyar dolar değer ile ikinci, 191,215 milyar dolar değerle Google ise üçüncü en değerli marka olarak tespit edilmiştir.

2021 yılı Türkiye'nin en değerli ve güçlü markalarının sıralamasının yer aldığı rapor Şekil 2.'de gösterilmektedir. 
Şekil 2. 2021 Yılı Türkiye 100 Marka Sıralaması

\begin{tabular}{|c|c|c|c|c|c|c|}
\hline 2021 & 2020 & Logo & Name & Country & 2021 & 2020 \\
\hline $1 \equiv$ & 1 & $0=$ & Turkish Airlines & ब & $\$ 1,605 \mathrm{M}$ & $\$ 1,975 \mathrm{M}$ \\
\hline $2 \wedge$ & 5 & sarçellik & Arçelik & ब & $\$ 1,585 \mathrm{M}$ & $\$ 1,273 M$ \\
\hline $3 \wedge$ & 8 & 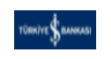 & İş Bankası & ब & $\$ 1,193 \mathrm{M}$ & $\$ 951 \mathrm{M}$ \\
\hline $4 v$ & 3 & scomonom & Garanti BBVA & G & $\$ 1,190 M$ & $\$ 1,538 \mathrm{M}$ \\
\hline $5 v$ & 4 & 2 & Turkcell & ब & $\$ 1,061 \mathrm{M}$ & $\$ 1,361 \mathrm{M}$ \\
\hline $6 v$ & 2 & Êtraxt Bntess & Ziraat Bankası & G & $\$ 952 M$ & $\$ 1,616 \mathrm{M}$ \\
\hline $7=$ & 7 & axeanur & Akbank & ब & $\$ 917 M$ & $\$ 998 \mathrm{M}$ \\
\hline $8 \wedge$ & 9 & - & Yapı Kredi & a & $\$ 836 \mathrm{M}$ & $\$ 876 \mathrm{M}$ \\
\hline$g \vee$ & 6 & mantis" & Türk Telekom & G & $\$ 789 M$ & $\$ 1,087 \mathrm{M}$ \\
\hline $10=$ & 10 & FORD OTOSAM & Ford Otosan & G & $\$ 787 M$ & $\$ 875 \mathrm{M}$ \\
\hline
\end{tabular}

Kaynak: www.brandirectory.com

Turkey-100, Türkiye'nin en değerli markaları sıralamasına göre 1,605 milyar dolar marka değeri ile Türk Hava Yolları Türkiye'nin en değerli markası seçilmiştir. Arçelik, 1,585 milyar dolar değer ile ikinci, 1,193 milyar dolar değerle Türkiye İş Bankası ise üçüncü en değerli marka olarak tespit edilmiştir.

Şekil 3’te ise, otomotiv sektörüne yönelik olarak 2021 yılı en değerli markalarını göstermektedir.

\section{Şekil 3. 2021 Yılı Otomotiv Sektörü 100 Marka Sıralaması}




\begin{tabular}{|c|c|c|c|c|c|c|}
\hline 2021 & 2020 & Logo & Name & Country & 2021 & 2020 \\
\hline $1 \wedge$ & 2 & 国 тоYota & Toyota & $\bullet$ & $\$ 59,479 M$ & $\$ 58,076 \mathrm{M}$ \\
\hline $2 \vee$ & 1 & (1) & Mercedes-Benz & = & $\$ 58,225 \mathrm{M}$ & $\$ 65,041 \mathrm{M}$ \\
\hline $3=$ & 3 & (D) & Volkswagen & E & $\$ 47,020 M$ & $\$ 44,897 \mathrm{M}$ \\
\hline $4=$ & 4 & (4) & BMW & E & $\$ 40,447 \mathrm{M}$ & $\$ 40,483 \mathrm{M}$ \\
\hline $5=$ & 5 & 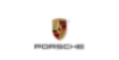 & Porsche & = & $\$ 34,326 \mathrm{M}$ & $\$ 33,911 \mathrm{M}$ \\
\hline $6 \wedge$ & 12 & $r$ & Tesla & 鉅 & $\$ 31,986 \mathrm{M}$ & $\$ 12,416 \mathrm{M}$ \\
\hline $7 \vee$ & 6 & 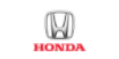 & Honda & - & $\$ 31,366 \mathrm{M}$ & $\$ 33,102 \mathrm{M}$ \\
\hline $8^{2}$ & 7 & $\therefore$ & Ford & 垔 & $\$ 22,676 \mathrm{M}$ & $\$ 18,515 \mathrm{M}$ \\
\hline $9 \wedge$ & 10 & 요 & Volvo & 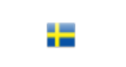 & $\$ 17,750 \mathrm{M}$ & $\$ 16,914 M$ \\
\hline $10 \mathrm{~V}$ & 9 & $\infty$ & Audi & 틀 & $\$ 17,187 \mathrm{M}$ & $\$ 16,973 \mathrm{M}$ \\
\hline
\end{tabular}

Kaynak: www.brandirectory.com

Otomotiv sektörü dünyanın en değerli markaları sıralamasına göre ise; 59,479 milyar dolar marka değeri ile Toyota Dünyanın en değerli markası seçilmiştir. Mercedes-Benz 58,225 milyar dolar değer ile ikinci, 47,020 milyar dolar değerle Volswagen ise üçüncü en değerli marka olarak tespit edilmiştir.

\section{Literatür}

Literatür incelendiğinde; marka değeri üzerine yapılan çalışmalarda, işletmelerin marka değerinin çeşitli yöntemlerle hesaplandığı görülmektedir. Aynı zamanda işletmelerin performans ölçümleri üzerine yapılan çalışmaların da fazlalığı dikkat çekmektedir. Yapılan çalışmalarda kullanılan yöntemlerde, çok kriterli karar verme tekniklerinin ön plana çıktığı tespit edilmiştir. Aşağıda otomotiv sanayi işletmelerinin performans ölçümü üzerine yapılan çalışmalara ve marka değeri ve performansın birlikte kullanıldığı çalışmalara da yer verilmiştir. Bununla birlikte, marka değeri ve performansın birlikte kullanıldığı çalışmaların sayı olarak az olduğu tespit edilmiş ve bu çalışmalar içinde otomotiv sektörü üzerine yapılan herhangi bir çalışmaya rastlanılmamıştır.

Ignatius vd. (2012) yaptıkları araştırmada, İran'ın en büyük sekiz otomotiv işletmesinin performansını Promethee II yöntemi ile incelemişlerdir.

Bulgurcu'nun (2013) çalışmasında, iMKB'de işlem gören otomotiv sektörü işletmelerinin performansları 20092012 yılları arasında TOPSIS yöntemi kullanılarak sıralanmıştır. Kriter ağırlıklarının belirlenmesinde ise entropi yöntemi kullanılmıştır. Analiz sonucunda dört yıl boyunca Federal Morgul i̇zmit Piston ve Pim Üretim A.Ş. en yüksek performans gösteren işletme olarak tespit edilmiştir.

Hsu vd. (2013) yaptıkları çalışmada, marka değeri ile pay senedi fiyatları arasında pozitif bir ilişki olduğunu ve marka değerindeki artışın, işletmelerin pay senedi getirilerini de artırdığını belirlemişlerdir. Bu çalışmada pay senedi getirileri performans ölçütü olarak ele alınmış ve marka değerinin performansa etkisi incelenmiştir.

Moradi ve Janatifar (2014) yapmış oldukları çalışmada, İran Tahran Borasında işlem gören altı otomotiv işletmesinin finansal performansını ölçerek sıralama gerçekleştirmiş̧ir. Elde ettikleri performans puanlarına göre en başarılı işletme, 0,974 puanla ilk sırada yer almıştır.

Wang vd.'nin (2015) 2010-2013 dönemini kapsayan çalışmalarında, Tayvan ileri teknoloji sektöründe faaliyet yürüten işletmelerin finansal bazlı marka değerlerinin, işletme performansını pozitif etkilediği sonucuna ulaşmışlardır.

Karakış ve Göktolga (2015) yaptıkları çalışmada, Borsa İstanbul'da faaliyette bulunan otomotiv imalat sektörü işletmelerinin performanslarını Electre ve Analitik Hiyerarşi Prosesi yöntemleri ile analiz etmişlerdir. Yapılan çalışmada 
öncelikle kriter ağırıklarını belirlemek için AHP yöntemi kullanılmış, sonrasında, performans puanlarını belirlemek için Electre yönteminden yararlanılmıştır. 2010-2014 yılları arasını kapsayan analizde Federal Morgul İzmit Piston ve Pim Üretim A.Ş. ve Ege Endüstri A.Ş.'nin yıllar itibariyle istikrarlı bir etkinliğe sahip olduğu görülmüştür.

Polat ve Peker'in (2016) çalışmasında, otomotiv sektöründeki işletmelerin performanslarına makro ekonomik değişkenlerin etkisi incelenmiştir. İşletmelerin performans göstergeleri olarak satış ve kar rakamları belirlenmiş ve makro ekonomik değişkenlerle korelasyon ve çoklu regresyon analizleriyle aralarındaki ilişki belirlenmiştir. Çalışma sonucunda otomotiv işletmelerinin performansları ile makro ekonomik değişkenler arasında orta ya da zayıf düzeyli bir ilişki olduğu belirlenmiştir.

Ömürbek vd. (2016) yaptıkları çalışmada, BIST'de işlem gören altı otomotiv işletmesinin, 2014 yılına ait performansını çok kriterli karar verme yöntemlerinden MAUT ve SAW yöntemleriyle incelemişler ve kriter ağılıklarını belirlemek için entropi yöntemini kullanmışlardır.

Mathur ve Agarwal (2016) Hindistan'da faaliyette bulunan Maruthi Suzuki ve Tata Motors işletmelerinin, 20122014 dönemindeki performanslarını incelemişler ve Maruthi Suzuki'nin daha iyi performans gösterdiğini tespit etmişlerdir.

Değer ve Aydoğan (2017) yaptıkları çalışmada finansal bazlı marka değerinin işletme performansına etkisini araştırmışlardır. 2009-2016 dönemlerinde BIST işlem gören 17 işletmenin dahil edildiği araştırmada marka değeri ile performans arasındaki ilişki panel veri yönteminden yararlanılarak analiz edilmiştir. Marka değeri olarak Hiroshi yöntemi ile belirlenen değerlerin kullanıldığı çalışmada performans göstergesi olarak da aktif getiri oranı ve özsermaye getiri oranı kullanılmışır. Araştırma sonucunda marka değerindeki artışın işletmelerin performanslarını artırdığı tespit edilmiştir.

Yanık ve Eren (2017) yaptıkları çalışmada, 2011-2015 yıllarını kapsayan dönemde BIST 100'de işlem gören otomotiv imalat sektöründeki 11 işletmeye ait verileri incelemişlerdir. Kriter ağılıklarını değerlendirmede analitik hiyerarşi prosesi yöntemini ve performans değerlemesinde çok kriterli karar verme yöntemlerinden Topsis, Vikor ve Electre yöntemlerini kullanmışlardır. Yaptıkları analiz sonucunda Federal Morgul izmit Piston ve Pim Üretim A.Ş., Ege Endüstri A.Ş. ve Bosch Fren Sistemleri A.Ş’nin üst sıralarda yer aldığı bulgusu elde edilmiştir.

Kayalı ve Aktaş (2018) yaptıkları çalışmada, pay senetleri BIST'de işlem gören yedi otomotiv işletmesinin performansını, 2010-2015 yılları arasında TOPSIS yöntemi ile ölçmüşlerdir. Yapılan değerlendirme sonucunda, Türk Traktör A.Ş. dört yıl en iyi performans gösteren işletme olarak ön plana çıkmıştır.

Yadav ve Kapoor (2018) yaptıkları çalışmalarında, 2012-2016 dönemlerinde Hindistan'da otomotiv sektöründe faaliyet gösteren on bir işletmenin performansını TOPSIS yöntemi ile değerlendirmişler ve kriter ağırıklarını da entropi yöntemi ile belirlemişlerdir. Analiz sonucunda 2012-2016 yılları arasında en iyi performans gösteren şirket her yıl aynı olarak tespit edilmiştir.

Esmer ve Dayı (2019) Borsa İstanbul'da (BIST) faaliyet gösteren otomotiv işletmelerinin 2010-2017 dönemine ilişkin 8 yıllık verilerinden faydalanılarak hesaplanan oranları kullandıkları çalışmalarında, açıklayıcı faktör analizi ve hiyerarşik kümeleme analizi yaparak, işletmelerin finansal performanslarını değerlendirmiştir. Çalışma sonucunda; açıklayıcı faktör analizi ile finansal performansını etkileyen faktörler belirlenirken kümeleme analizi ile Ford ile Otokar işletmelerinin birbirlerine en yakın; Karsan ile Federal Mogul işletmelerinin ise birbirlerine en uzak performansa sahip oldukları tespit edilmiştir.

Tezcan'ın (2019) Türkiye otomotiv sanayindeki işletmelerin performansları ile ihracat düzeyleri arasındaki ilişkiyi incelediği çalışmasında, 2016-2018 döneminde Borsa İstanbul'da işlem gören otomotiv işletmelerini finansal performanslarına göre sıralamıştır. Performans sıralamasında TOPSIS yönteminin kullanıldı̆̆ı bu çalışma sonucunda, 2016-2018 yılları arasında en iyi performans gösteren işletme, her yıl Ford Oto olarak belirlenmiştir.

Apan (2020) ise çalışmasında bankaların marka değeri ile performanslarını karşılaştırmalı olarak incelemiştir. 2012-2018 döneminde yapılan araştırmada marka performansları marka değerlerine dayalı olarak belirlenmiş ve bankaların performanslarını belirlemek için de entropi ağırlıklandırma ve TOPSIS yöntemlerinden yararlanıımıştır. Sonuç olarak bankaların altı tanesinin marka değeri değişimlerinin performansa yansıdığı ancak dört bankanın marka değeri değişimlerinin performansa yansımadığı tespit edilmiştir.

\section{Metodoloji}

\section{1. Çalışmanın Amacı, Kapsamı ve Veri Seti}


Çalışma kapsamında Brand Finance Türkiye 100 sıralamasında bulunan otomotiv sektörü işletmelerinin performansları Entropi Temelli TOPSis yöntemi ile değerlendirilerek ilgili işletmelerin Brand Finance Türkiye 100 sıralamaları ile performans sıralamalarının karşılaştırmalı olarak analiz edilmesi amaçlanmıştır. Bu amaçla Brand Finance Türkiye 100 sıralamasında otomotiv sektöründe faaliyetlerini yürüten işletmeler olarak belirtilen dokuz işletmeden Borsa ìstanbul'da işlem gören sekiz işletme araştırmanın kapsamını oluşturmaktadır. Çalışmanın kapsamını oluşturan işletme listesi Tablo 1'de sunulmuştur.

Tablo 1. Çalışma Kapsamını Oluşturan İşletme Listesi

\begin{tabular}{|l|l|l|}
\hline No & BIST İşletme Kodu & \multicolumn{1}{c|}{ İşletme Unvanı } \\
\hline 1 & ASUZU & Anadolu Isuzu Otomotiv Sanayi ve Ticaret A.Ş. \\
\hline 2 & DOAS & Doğuş Otomotiv Servis ve Ticaret A.Ş. \\
\hline 3 & FROTO & Ford Otomotiv Sanayi A.Ş. \\
\hline 4 & KARSN & Karsan Otomotiv Sanayii ve Ticaret A.Ş. \\
\hline 5 & OTKAR & Otokar Otomotiv ve Savunma Sanayi A.Ş. \\
\hline 6 & OTOKC & Otokoç Otomotiv Ticaret ve Sanayi A.Ş. \\
\hline 7 & TOASO & Tofaş Türk Otomobil Fabrikası A.Ş. \\
\hline 8 & TTRAK & Türk Traktör ve Ziraat Makineleri A.Ş. \\
\hline
\end{tabular}

Çalışma kapsamına dahil edilen işletmelerin performans ölçümünde kullanılacak kriterler, ilgili literatür incelenerek belirlenmiştir. Literatürde ağırlıklı olarak finansal performans incelenmiş ve finansal analizde kullanılan bütün finansal oranlar araştırmalarda kullanılmıştır. Yapılan bu çalışmada ise amaç, genel performansa dayalı bir sıralama yapmaktır. Bu nedenle işletmelerin performansını ortaya koyan karlııı ile ilgili finansal oranlar çalışmanın kriterleri olarak belirlenmiştir. Aynı zamanda kontrol değişkeni olarak da işletmelerin aktif büyüklüğü, satışlar, faaliyet giderleri ve finansal kaldıraç oranı karar kriteri olarak eklenmiştir. Çalışmanın karar kriterleri Tablo 2'de gösterilmiştir. Karar kriterleri, ilgili işletmelerin Kamuyu Aydınlatma Platformu (KAP)'da ilan ettikleri bağımsız denetimden geçmiş finansal raporlarından elde edilmiştir.

Tablo 2. Çalışmada Kullanılan Karar Değişkenleri

\begin{tabular}{|l|l|l|l|}
\hline No & Kod & \multicolumn{1}{|c|}{ Karar Kriterleri } & \multicolumn{1}{c|}{ Formüller } \\
\hline 1 & K1 & Aktif Karlıık Oranı & Net Kar/Aktif Toplamı \\
\hline 2 & K2 & Özsermaye Karıııı Oranı & Net Kar/Özsermaye Toplamı \\
\hline 3 & K3 & Net Kar Marjı & Net kar/Satışlar \\
\hline 4 & K4 & Faaliyet Kar Oranı & Faaliyet Karı/Satışlar \\
\hline 5 & K5 & Aktif Büyüklüğü & Aktif Toplamı \\
\hline 6 & K6 & Net Satışlar & Satışlar \\
\hline 7 & K7 & Faaliyet Giderleri & Faaliyet Giderleri \\
\hline 8 & K8 & Finansal Kaldıraç Oranı & Toplam Borç/Aktif Toplamı \\
\hline
\end{tabular}

\section{2. Çalışmanın Yöntemi}

Çalışma kapsamına dahil edilen işletmelerin öncelikle Brand Finance Türkiye 100 sıralamasındaki yerleri tespit edilmiştir. Daha sonra ilgili işletmelerin performans sıralamaları için Entropi temelli TOPSIS yöntemi kullanılmıştır. Bu yöntemler ile ilgili bilgiler aşağıda verilmiştir. Burada entropi yöntemi ile kriterlerin ağırlıkları hesaplanmış ve belirlenen bu kriter ağırlıkları kullanılarak TOPSIS yöntemi ile işletmelerin performans sıralamaları belirlenmiştir. Son olarak da yıllar itibariyle bulunan performans sıralamaları ile Brand Finance Türkiye sıralamaları karşılaştııımıştır.

\subsection{Brand Finance}

Brand Finance bağımsız bir marka değerleme danışmanlık şirketidir. 1996 yılında kurulan kuruluşun amacı pazarlama ile finans arasında köprü kurmaktır. Şirket her yıl dünya üzerinde 5.000'den fazla işletmeyi incelemekte ve markaları ülke ve sektör bazında sıralamak suretiyle yılda 100'e yakın rapor yayınlamaktadır. Şirket marka değeri hesaplarken öncelikle markanın etkisini ve marka gücünü hesaplamakta daha sonra tahmini marka değerine ulaşmaktadır. Şirketin kullandığı yöntemler, uluslararası ISO 10668 Marka Değerleme Standardına uygunluğunun yanı sıra Marketing Accountability Standarts Board tarafından onaylanmıştır. Brand Finance marka değerlemede kullandığı yöntemler ile International Valuation Standards Council üyesi tek marka değerleme şirketi olarak faaliyetlerini sürdürmektedir (Brand Finance Türkiye 100, 2021). 


\subsection{Entropi Yöntemi}

Entropi yöntemi, termodinamikte düzensizlik ve dağınıklığın bir ölçütü olarak biçiminde ifade edilmiştir. Evrende kendi haline ve doğal şartlara bırakılan tüm sistemlerin zamana bağlı olarak dağınıklığa ve düzensizliğe uğrayıp bozulacağı anlamına gelmektedir. Entropi kavramı 1948'de Shannon tarafından bilgi entropisi olarak tanımlanmıştır. Buna göre entropi, rassal değişkenlerdeki belirsizliğin ölçütüdür. Shannon'un çalışması ile birlikte entropi yöntemi fiziğin yanı sıra sosyal bilimlerde de kullanılan bir yöntem olmuştur. Entropi yöntemi karar matrisinin oluşturulmasında kullanılan kriterlerin ağırıklarının objektif olarak belirlenmesini sağlayan bir yöntemdir. Sosyal bilimlerde olasılık teorisi kullanılarak formülize edilmiş olan enformasyondaki belirsizlik ölçüsü olarak ifade edilmektedir. Belirlenen kritik değerlerin dağılım derecesi arttıkça, kriterlerin değerlendirme üzerinde var olan etkisi de artış göstermektedir (Zhang vd.,2011:444; Hwang ve Yoon, 1981: 52; Deng vd., 2000; Shemshadi vd., 2011; Tunca vd., 2016: 8; Ömürbek ve Balcı, 2017: 15-16; Wang ve Lee, 2009: 8982; Akçakanat vd., 2017: 290; Perçin ve Sönmez, 2018: 570).

Entropi yöntemi beş aşamadan oluşan bir süreci kapsamaktadır. Bu aşamalar kısaca şu şekilde özetlenebilmektedir (Sakarya ve Aksu, 2020: 26; Erol ve Ferrell, 2009: 1196-1197; Çanakçıoğlu ve Küçükönder, 2020: 205-206; Wang ve Lee, 2009: 8982; Özdağoğlu vd..2017: 346-347; Ayçin, 2019: 123-124):

1. Aşama: Karar Matrisinin Oluşturulması: Birinci aşamada $x_{i j}$ değerlerinden meydana gelen $D$ karar matrisi oluşturulur.

$$
D=\begin{gathered}
A_{1} \\
A_{2} \\
\vdots \\
A_{m}
\end{gathered}\left[\begin{array}{cccc}
x_{11} & x_{12} & \ldots & x_{1 n} \\
x_{21} & x_{22} & \ldots & x_{2 n} \\
\vdots & \vdots & \ldots & \vdots \\
x_{m 1} & x_{m 2} & \ldots & x_{m n}
\end{array}\right]
$$

2. Aşama: Karar Matrisinin Normalizasyonu: İkinci aşamada kriterlere ilişkin değerler normalizasyon işlemiyle standart hale getirilir. Normalizasyon işlemi Eşitlik (2)'de gösterilen hesaplama ile yapılır.

$$
p_{i j}=\frac{x_{i j}}{\sum_{i=1}^{m} x_{i j}} \forall i, j
$$

3. Aşama: Kriterlere Illişkin Entropi Değerlerinin Bulunması: Üçüncü aşamada kriterlerin entropi değerleri Eşitlik (3)'te gösterilen yöntemle hesaplanır.

$$
e_{i j}=-k \cdot \sum_{j=1}^{n} p_{i j} \cdot \ln \left(p_{i j}\right) \quad i=1,2, \ldots, m \text { ve } j=1,2, \ldots, n
$$

4. Aşama: Farklılaşma Derecelerinin Bulunması: Dördüncü aşamada hesaplanan entropi değerleri kullanılarak farklılaşma dereceleri Eşitlik (4)'de gösterilen formülle hesaplanır.

$$
d_{j}=1-e_{j} \quad j=1,2, \ldots, n
$$

5. Aşama: Entropi Kriter Ağırlıklarının Hesaplanması: En son aşamada her bir kritere ait farklılaşma derecesi, toplam farklılaşma derecesine oranlanarak kriter ağırlıkları elde edilir.

$$
w_{j}=\frac{d_{j}}{\sum_{j=1}^{n} d_{j}}
$$

Entropi yönteminin üçüncü aşamasında entropi değerleri hesaplanırken kriterlerin doğal logaritması kullanılmaktadır. Ancak kriterlerin negatif değerler olması durumunda logaritmaları alınamayacağından dolayı ilgili 
kriterlerin Z skorları hesaplanarak pozitif değerler almaları sağlanmakta ve yeni değerler ile entropi değerleri hesaplanarak süreç devam etmektedir. Z skorlarının hesaplanmasında Eşitlik (6) ve Eşitlik (7)'den yararlanılmaktadır (Zhang vd., 2014).

$$
\begin{gathered}
z_{i j}=\frac{x_{i j}-\overline{X_{j}}}{\sigma_{j}} \\
z_{i j}^{\prime}=z_{i j}+A ; \quad A>\left|\min z_{i j}\right|
\end{gathered}
$$

\subsection{TOPSIS Yöntemi}

Hwang ve Yoon (1981) tarafından önerilen TOPSIS yöntemi ideale yakınlığı temsil eden toplam fonksiyon temelli bir uzlaşma yöntemidir. TOPSIS yönteminde pozitif ideale en yakın ve negatif ideale en uzak bir çözüm bulunması amaçlanmıştır (Chen, 2000: 2). Farklı ölçüm birimlerini ortadan kaldırmak ve kıyaslama yapabilmek için normalizasyonda vektör standartlaştırmasından faydalanılmıştır (Ecer, 2020: 146). TOPSIS yöntemi seçilen alternatifin aynı zamanda ideal ve ideal olmayan çözümlerini de ortaya koyan bir yöntemdir (Wang vd., 2009: 377; Keskin ve Altan, 2020: 71).

Çalışmada alternatiflerin sıralamasında çok kriterli karar verme tekniklerinden TOPSIS yönteminin kullanılmasının başlıca nedenleri arasında; performans açısından alternatif sayısından ve kriter sayılarının değişmesinden çok fazla etkilenmemesi ve sıralama değişimi konusunda en iyi tepki veren yöntem olarak değerlendirilmesi gösterilebilmektedir (Vatansever, 2013).

TOPSIS yöntemi altı aşamadan oluşan bir süreçtir (Ecer, 2020: 147-149; Keskin ve Altan, 2020: 73-75; Ayçin, 2019: 239-242; Organ ve Kaçaroğlu, 2020: 32-33; Özkan, 2020: 52-55; Apan, 2020: 499):

1.Aşama: Karar Matrisinin Oluşturulması: Alternatiflerin kriterlere göre aldıkları değerlerden oluşan başlangıç matrisi oluşturulur. $A_{i j}$ matrisinde $m$ alternatif ve $n$ kriterden oluşan bir karar matrisidir. Eşitlik (8) karar matrisini göstermektedir.

$$
A_{i j}=\left[\begin{array}{cccc}
a_{11} & a_{12} & \ldots & a_{1 n} \\
a_{21} & a_{22} & \ldots & a_{2 n} \\
\vdots & \vdots & \ldots & \vdots \\
a_{m 1} & a_{m 2} & \ldots & a_{m n}
\end{array}\right]
$$

2. Aşama: Standart Karar Matrisinin Oluşturulması (Normalizasyon): Standartlaştırma işleminde karar matrisi elemanlarının her biri Eşitlik (9)'deki formül yardımıyla normalizasyon işlemine tabi tutulur ve elde edilen değerler ile Eşitlik (10)'da gösterilen $R_{i j}$ Standartlaştırıımış Karar Matrisi elde edilir.

$$
\begin{aligned}
r_{i j} & =\frac{a_{i j}}{\sqrt{\sum_{k=1}^{m} a_{k j}^{2}}} \quad i=1,2, \ldots, m ; \quad j=1,2, \ldots, n \\
R_{i j} & =\left[\begin{array}{cccc}
r_{11} & r_{12} & \ldots & r_{1 n} \\
r_{21} & r_{22} & \ldots & r_{2 n} \\
\vdots & \vdots & \ldots & \vdots \\
r_{m 1} & r_{m 2} & \ldots & r_{m n}
\end{array}\right]
\end{aligned}
$$


3. Aşama: Ağırlıklandırılmış Standart Karar Matrisinin Oluşturulması: Üçüncü aşamada standart karar matrisi kriter ağırlıkları kullanılarak ağırıklandııılmış standart karar matrisine dönüştürülür. Kriter ağılıkları belirlenirken sübjektif ve objektif yöntemlerden yararlanılabilir. Standart karar matrisinin her bir elemanı kriter ağırıkları $\left(w_{n}\right)$ ile çarpılarak standart karar matrisi ağırlıklandırılmış olur ve Eşitlik (11)'deki $V_{i j}$ matrisi elde edilir.

$$
V_{i j}=\left[\begin{array}{cccc}
w_{1} r_{11} & w_{2} r_{12} & \ldots & w_{n} r_{1 n} \\
w_{1} r_{21} & w_{2} r_{22} & \ldots & w_{n} r_{2 n} \\
\vdots & \vdots & \ldots & \vdots \\
w_{1} r_{m 1} & w_{2} r_{m 2} & \ldots & w_{n} r_{m n}
\end{array}\right]
$$

4. Aşama: Pozitif İdeal ve Negatif İdeal Çözüm Değerlerinin Belirlenmesi: $V_{i j}$ matrisinin her sütunundaki en yüksek değer pozitif ideal ve en düşük değer ise negatif ideal değerdir. Eşitlik (12) ve Eşitlik (13) bu durumu ifade etmektedir.

$$
\begin{aligned}
& A^{*}=\left\{\left(\max _{i} v_{i j} \mid j \in J\right),\left(\begin{array}{cc}
\min _{i} & v_{i j} \mid j \in J^{\prime} \\
i &
\end{array}\right)\right\} \\
& A^{*}=\left\{\left(\min _{i} v_{i j} \mid j \in J\right),\left(\max _{i} v_{i j} \mid j \in J^{\prime}\right)\right\}
\end{aligned}
$$

5. Aşama: Pozitif ve Negatif İdeal Noktalara Olan Uzaklığın Hesaplanması: Alternatiflerin pozitif ve negatif ideal çözümlerden sapmaları Öklid uzaklığı ile hesaplanır. Eşitlik (14) ve Eşitlik (15) yardımıyla her bir alternatifin pozitif ve negatif ideal çözümden uzaklı̆̆ı hesap edilir.

$$
\begin{aligned}
& S_{i}^{*}=\sqrt{\sum_{j=1}^{n}\left(v_{i j}-v_{j}^{*}\right)^{2}} \\
& S_{i}^{-}=\sqrt{\sum_{j=1}^{n}\left(v_{i j}-v_{j}^{-}\right)^{2}}
\end{aligned}
$$

6. Aşama: İdeal Çözüme Göreli Yakınlığın Hesaplanması: Alternatiflerin ideal çözüme yakınlığı Eşitlik (16) yardımıyla belirlenir. Bütün alternatiflerin göreli yakınlığı hesaplandıktan sonra en büyük değere sahip olan alternatif en iyi seçim olarak kabul edilir.

$$
C_{i}^{*}=\frac{S_{i}^{-}}{S_{i}^{-}+S_{i}^{*}}
$$

\section{Bulgular}


Çalışmada öncelikle 2018, 2019 ve 2020 yılları için Brand Finance Türkiye 100 sıralamasında bulunan işletmelerin sıralamaları ve marka değerleri çıkarılmışır. Tablo 3'te bu sıralamalar gösterilmektedir. Yıllara göre sıralamalar oluşturulurken her yıl açıklanan raporların bir önceki yılın değerlerini içerdiği belirlendiğinden 2020 yılı verileri için Brand Finance Türkiye 1002021 raporu, 2019 yılı için Brand Finance Türkiye 1002020 raporu ve 2018 yılı verileri için de Brand Finance Türkiye 1002019 raporu dikkate alınmıştır.

Tablo 3. Brand Finance Türkiye 100 Otomotiv Sektörü Sıralamaları

\begin{tabular}{|l|l|l|l|l|l|l|l|l|}
\hline \multicolumn{3}{|c|}{2018} & \multicolumn{3}{c|}{2019} & \multicolumn{3}{c|}{2020} \\
\hline & $\begin{array}{l}\text { Marka Değeri } \\
\text { (Milyon \$) }\end{array}$ & Sıralama & & $\begin{array}{l}\text { Marka Değeri } \\
\text { (Milyon \$) }\end{array}$ & Siralama & $\begin{array}{l}\text { Marka Değeri } \\
\text { (Milyon \$) }\end{array}$ & Sıralama \\
\hline FROTO & 458 & 1 & FROTO & 875 & 1 & FROTO & 787 & 1 \\
\hline TOASO & 299 & 2 & TOASO & 354 & 2 & TOASO & 336 & 2 \\
\hline DOAS & 186 & 3 & DOAS & 242 & 3 & DOAS & 235 & 3 \\
\hline TTRAK & 109 & 4 & OTKAR & 159 & 4 & TTRAK & 111 & 4 \\
\hline OTKAR & 66 & 5 & TTRAK & 130 & 5 & OTOKC & 104 & 5 \\
\hline KARSN & 22 & 6 & KARSN & 26 & 6 & OTKAR & 91 & 6 \\
\hline ASUZU & 17 & 7 & ASUZU & 26 & 7 & KARSN & 34 & 7 \\
\hline OTOKC & - & 8 & OTOKC & - & 8 & ASUZU & 22 & 8 \\
\hline
\end{tabular}

Kaynak: Brand Finance Türkiye 100 2019, 2020 ve 2021

Brand Finance Türkiye sıralamaları belirlendikten sonra çalışma kapsamındaki işletmelerin performans değerlendirmesi için TOPSIS yöntemi tercih edilmiştir. TOPSIS yönteminde karar kriterlerinin ağılık değerlerinin kullanılması gerekmektedir. Kriterlerin ağırlık değerlerinin belirlenmesinde kullanılan çeşitli yöntemler mevcuttur. Bu yöntemler sübjektif ve objektif yöntemler olarak ikiye ayrılmaktadır. Kriter ağılık değerlerinin sonuç üzerindeki etkisi de göz önüne alındığında ve literatürde yapılan incelemeler sonucunda kriter ağırlıklarının belirlenmesinde objektif yöntemlerden entropi yönteminin kullanılmasının uygun olduğuna karar verilmiştir.

Entropi yöntemi için ilk olarak 2018, 2019 ve 2020 yıllarına ait karar kriterlerinden oluşan karar matrisi Tablo 4'te oluşturulmuştur.

Tablo 4. Karar Matrisi

\begin{tabular}{|c|c|c|c|c|c|c|c|c|c|}
\hline \multirow{9}{*}{2018} & İşletmeler/Kriterler & K1 & K2 & K3 & K4 & K5 & K6 & K7 & K8 \\
\hline & ASUZU & $-0,05$ & $-0,147$ & $-0,067$ & 0,033 & 1599665 & 1187862 & 144510 & 0,659 \\
\hline & DOAS & 0,027 & 0,102 & 0,012 & 0,049 & 4798662 & 10688489 & 774426 & 0,727 \\
\hline & FROTO & 0,127 & 0,432 & 0,05 & 0,068 & 13184440 & 33292030 & 1173698 & 0,704 \\
\hline & KARSN & $-0,009$ & $-0,071$ & $-0,016$ & 0,157 & 2359885 & 1441587 & 52427 & 0,861 \\
\hline & OTKAR & 0,071 & 0,421 & 0,097 & 0,137 & 2302746 & 1678661 & 360545 & 0,83 \\
\hline & OTOKC & 0,052 & 0,3 & 0,056 & 0,116 & 8043164 & 7545958 & 572418 & 0,824 \\
\hline & TOASO & 0,102 & 0,358 & 0,071 & 0,063 & 13001799 & 18603331 & 1335840 & 0,714 \\
\hline & TTRAK & 0,077 & 0,368 & 0,061 & 0,14 & 3093253 & 3908943 & 281613 & 0,439 \\
\hline \multirow{3}{*}{2019} & İşletmeler/Kriterler & K1 & K2 & K3 & K4 & K5 & K6 & K7 & K8 \\
\hline & ASUZU & 0,013 & 0,038 & 0,015 & 0,08 & 1576444 & 1422987 & 144278 & 0,642 \\
\hline & DOAS & 0,016 & 0,061 & 0,007 & 0,049 & 4664944 & 9844133 & 783601 & 0,731 \\
\hline
\end{tabular}




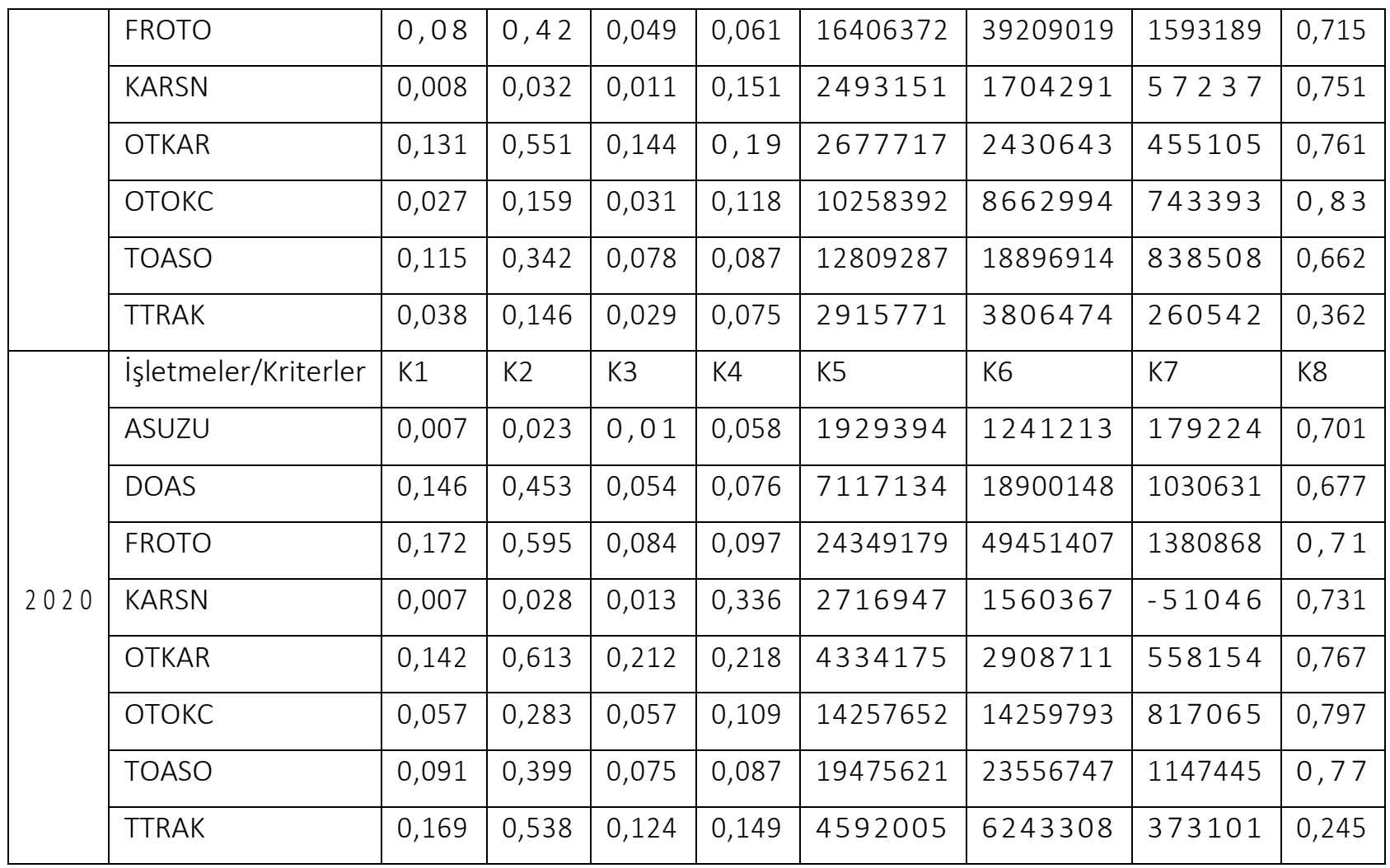

Karar matrisi incelendiğinde kriterlerin bir kısmının negatif verilerden oluştuğu görülmektedir. Negatif verilerin bulunduğu karar kriterleri sütunları Eşitlik (6) ve Eşitlik (7) yardımıyla düzenlemiş ve analize hazır hale getirilmiştir. Düzeltilmiş karar matrisi Tablo 5'te ifade edilmiştir.

Tablo 5. Düzeltilmiş Karar Matrisi

\begin{tabular}{|c|c|c|c|c|c|c|c|c|c|}
\hline \multirow{9}{*}{2018} & İşletmeler/Kriterler & K1 & K2 & K3 & K4 & K5 & K6 & K7 & K8 \\
\hline & ASUZU & 0,100 & 0,100 & 0,100 & 0,033 & 1599665 & 1187862 & 144510 & 0,659 \\
\hline & DOAS & 1,420 & 1,189 & 1,579 & 0,049 & 4798662 & 10688489 & 774426 & 0,727 \\
\hline & FROTO & 3,135 & 2,633 & 2,290 & 0,068 & 13184440 & 33292030 & 1173698 & 0,704 \\
\hline & KARSN & 0,803 & 0,433 & 1,055 & 0,157 & 2359885 & 1441587 & 52427 & 0,861 \\
\hline & OTKAR & 2,174 & 2,584 & 3,170 & 0,137 & 2302746 & 1678661 & 360545 & 0,83 \\
\hline & OTOKC & 1,849 & 2,055 & 2,402 & 0,116 & 8043164 & 7545958 & 572418 & 0,824 \\
\hline & TOASO & 2,706 & 2,309 & 2,683 & 0,063 & 13001799 & 18603331 & 1335840 & 0,714 \\
\hline & TTRAK & 2,277 & 2,353 & 2,496 & 0,14 & 3093253 & 3908943 & 281613 & 0,439 \\
\hline \multirow{8}{*}{2019} & İşletmeler/Kriterler & K1 & K2 & K3 & K4 & K5 & K6 & K7 & K8 \\
\hline & ASUZU & 0,013 & 0,038 & 0,015 & 0,08 & 1576444 & 1422987 & 144278 & 0,642 \\
\hline & DOAS & 0,016 & 0,061 & 0,007 & 0,049 & 4664944 & 9844133 & 783601 & 0,731 \\
\hline & FROTO & 0,08 & 0,42 & 0,049 & 0,061 & 16406372 & 39209019 & 1593189 & 0,715 \\
\hline & KARSN & 0,008 & 0,032 & 0,011 & 0,151 & 2493151 & 1704291 & 57237 & 0,751 \\
\hline & OTKAR & 0,131 & 0,551 & 0,144 & 0,19 & 2677717 & 2430643 & 455105 & 0,761 \\
\hline & OTOKC & 0,027 & 0,159 & 0,031 & 0,118 & 10258392 & 8662994 & 743393 & 0,83 \\
\hline & TOASO & 0,115 & 0,342 & 0,078 & 0,087 & 12809287 & 18896914 & 838508 & 0,662 \\
\hline
\end{tabular}




\begin{tabular}{|l|l|l|l|l|l|l|l|l|l|}
\hline & TTRAK & 0,038 & 0,146 & 0,029 & 0,075 & 2915771 & 3806474 & 260542 & 0,362 \\
\hline \multirow{6}{*}{2020} & Işletmeler/Kriterler & $\mathrm{K} 1$ & $\mathrm{~K} 2$ & $\mathrm{~K} 3$ & $\mathrm{~K} 4$ & $\mathrm{~K} 5$ & $\mathrm{~K} 6$ & $\mathrm{~K} 7$ & $\mathrm{~K} 8$ \\
\cline { 2 - 10 } & ASUZU & 0,007 & 0,023 & 0,01 & 0,058 & 1929394 & 1241213 & 0,561 & 0,701 \\
\cline { 2 - 10 } & DOAS & 0,146 & 0,453 & 0,054 & 0,076 & 7117134 & 18900148 & 2,266 & 0,677 \\
\cline { 2 - 10 } & FROTO & 0,172 & 0,595 & 0,084 & 0,097 & 24349179 & 49451407 & 2,967 & 0,71 \\
\cline { 2 - 10 } & KARSN & 0,007 & 0,028 & 0,013 & 0,336 & 2716947 & 1560367 & 0,100 & 0,731 \\
\cline { 2 - 10 } & OTKAR & 0,142 & 0,613 & 0,212 & 0,218 & 4334175 & 2908711 & 1,320 & 0,767 \\
\cline { 2 - 10 } & OTOKC & 0,057 & 0,283 & 0,057 & 0,109 & 14257652 & 14259793 & 1,838 & 0,797 \\
\cline { 2 - 9 } & TOASO & 0,091 & 0,399 & 0,075 & 0,087 & 19475621 & 23556747 & 2,500 & 0,77 \\
\cline { 2 - 9 } & TTRAK & 0,169 & 0,538 & 0,124 & 0,149 & 4592005 & 6243308 & 0,949 & 0,245 \\
\hline
\end{tabular}

Düzeltilmiş karar matrisindeki değerler kullanılarak veriler normalize edilmiştir. Normalize edilmiş karar matrisi tablosu Tablo 6'da gösterilmiştir.

Tablo 6. Normalize Edilmiş Karar Matrisi

\begin{tabular}{|c|c|c|c|c|c|c|c|c|c|}
\hline \multirow{9}{*}{2018} & İşletmeler/Kriterler & K1 & K2 & K3 & K4 & K5 & K6 & K7 & K8 \\
\hline & ASUZU & 0,007 & 0,007 & 0,006 & 0,043 & 0,033 & 0,015 & 0,031 & 0,114 \\
\hline & DOAS & 0,098 & 0,087 & 0,100 & 0,064 & 0,099 & 0,136 & 0,165 & 0,126 \\
\hline & FROTO & 0,217 & 0,193 & 0,145 & 0,089 & 0,272 & 0,425 & 0,250 & 0,122 \\
\hline & KARSN & 0,056 & 0,032 & 0,067 & 0,206 & 0,049 & 0,018 & 0,011 & 0,150 \\
\hline & OTKAR & 0,150 & 0,189 & 0,201 & 0,180 & 0,048 & 0,021 & 0,077 & 0,144 \\
\hline & OTOKC & 0,128 & 0,151 & 0,152 & 0,152 & 0,166 & 0,096 & 0,122 & 0,143 \\
\hline & TOASO & 0,187 & 0,169 & 0,170 & 0,083 & 0,269 & 0,237 & 0,284 & 0,124 \\
\hline & TTRAK & 0,157 & 0,172 & 0,158 & 0,183 & 0,064 & 0,050 & 0,060 & 0,076 \\
\hline \multirow{9}{*}{2019} & İşletmeler/Kriterler & K1 & K2 & K3 & K4 & K5 & K6 & K7 & K8 \\
\hline & ASUZU & 0,030 & 0,022 & 0,041 & 0,099 & 0,029 & 0,017 & 0,030 & 0,118 \\
\hline & DOAS & 0,037 & 0,035 & 0,019 & 0,060 & 0,087 & 0,114 & 0,161 & 0,134 \\
\hline & FROTO & 0,187 & 0,240 & 0,135 & 0,075 & 0,305 & 0,456 & 0,327 & 0,131 \\
\hline & KARSN & 0,019 & 0,018 & 0,030 & 0,186 & 0,046 & 0,020 & 0,012 & 0,138 \\
\hline & OTKAR & 0,306 & 0,315 & 0,396 & 0,234 & 0,050 & 0,028 & 0,093 & 0,140 \\
\hline & OTOKC & 0,063 & 0,091 & 0,085 & 0,145 & 0,191 & 0,101 & 0,152 & 0,152 \\
\hline & TOASO & 0,269 & 0,196 & 0,214 & 0,107 & 0,238 & 0,220 & 0,172 & 0,121 \\
\hline & TTRAK & 0,089 & 0,083 & 0,080 & 0,092 & 0,054 & 0,044 & 0,053 & 0,066 \\
\hline \multirow{5}{*}{2020} & İşletmeler/Kriterler & K1 & K2 & K3 & K4 & K5 & K6 & K7 & K8 \\
\hline & ASUZU & 0,009 & 0,008 & 0,016 & 0,051 & 0,024 & 0,011 & 0,045 & 0,130 \\
\hline & DOAS & 0,185 & 0,155 & 0,086 & 0,067 & 0,090 & 0,160 & 0,181 & 0,125 \\
\hline & FROTO & 0,217 & 0,203 & 0,134 & 0,086 & 0,309 & 0,419 & 0,237 & 0,132 \\
\hline & KARSN & 0,009 & 0,010 & 0,021 & 0,297 & 0,034 & 0,013 & 0,008 & 0,135 \\
\hline
\end{tabular}




\begin{tabular}{|l|l|l|l|l|l|l|l|l|l|}
\hline & OTKAR & 0,180 & 0,209 & 0,337 & 0,193 & 0,055 & 0,025 & 0,106 & 0,142 \\
\cline { 2 - 9 } & OTOKC & 0,072 & 0,097 & 0,091 & 0,096 & 0,181 & 0,121 & 0,147 & 0,148 \\
\cline { 2 - 8 } & TOASO & 0,115 & 0,136 & 0,119 & 0,077 & 0,247 & 0,199 & 0,200 & 0,143 \\
\cline { 2 - 9 } & TTRAK & 0,214 & 0,183 & 0,197 & 0,132 & 0,058 & 0,053 & 0,076 & 0,045 \\
\hline
\end{tabular}

Normalize edilen karar matrisi değerleri kullanılarak kriterlerin entropi değerleri hesaplanmıştır. Hesaplanan entropi değerleri (ej) Tablo 7'de gösterilmiştir.

Tablo 7. Karar Kriterlerine illişkin Entropi Değerleri

\begin{tabular}{|c|c|c|c|c|c|c|c|c|c|}
\hline \multirow{11}{*}{2018} & İşletmeler/Kriterler & K1 & K2 & K3 & K4 & K5 & K6 & K7 & K8 \\
\hline & ASUZU & $-0,034$ & $-0,036$ & $-0,032$ & $-0,136$ & $-0,113$ & $-0,064$ & $-0,107$ & $-0,248$ \\
\hline & DOAS & $-0,228$ & $-0,213$ & $-0,230$ & $-0,176$ & $-0,229$ & $-0,272$ & $-0,297$ & $-0,261$ \\
\hline & FROTO & $-0,331$ & $-0,317$ & $-0,280$ & $-0,215$ & $-0,354$ & $-0,364$ & $-0,347$ & $-0,257$ \\
\hline & KARSN & $-0,160$ & $-0,109$ & $-0,181$ & $-0,325$ & $-0,147$ & $-0,074$ & $-0,050$ & $-0,284$ \\
\hline & OTKAR & $-0,285$ & $-0,315$ & $-0,322$ & $-0,308$ & $-0,145$ & $-0,082$ & $-0,197$ & $-0,279$ \\
\hline & OTOKC & $-0,263$ & $-0,285$ & $-0,287$ & $-0,286$ & $-0,298$ & $-0,225$ & $-0,257$ & $-0,278$ \\
\hline & TOASO & $-0,314$ & $-0,301$ & $-0,301$ & $-0,206$ & $-0,353$ & $-0,341$ & $-0,358$ & $-0,259$ \\
\hline & TTRAK & $-0,291$ & $-0,303$ & $-0,292$ & $-0,311$ & $-0,176$ & $-0,150$ & $-0,169$ & $-0,196$ \\
\hline & $\ln (8)=0,481$ & & & & & & & & \\
\hline & $e_{j}$ & 0,917 & 0,904 & 0,926 & 0,945 & 0,873 & 0,756 & 0,857 & 0,992 \\
\hline \multirow{11}{*}{2019} & İşletmeler /Kriterler & K1 & K2 & K3 & K4 & K5 & K6 & K7 & K8 \\
\hline & ASUZU & $-0,106$ & $-0,083$ & $-0,131$ & $-0,228$ & $-0,103$ & $-0,068$ & $-0,104$ & $-0,252$ \\
\hline & DOAS & $-0,123$ & $-0,117$ & $-0,076$ & $-0,170$ & $-0,212$ & $-0,248$ & $-0,294$ & $-0,269$ \\
\hline & FROTO & $-0,313$ & $-0,343$ & $-0,270$ & $-0,195$ & $-0,362$ & $-0,358$ & $-0,365$ & $-0,266$ \\
\hline & KARSN & $-0,074$ & $-0,073$ & $-0,106$ & $-0,313$ & $-0,142$ & $-0,078$ & $-0,052$ & $-0,273$ \\
\hline & OTKAR & $-0,362$ & $-0,364$ & $-0,367$ & $-0,340$ & $-0,149$ & $-0,101$ & $-0,221$ & $-0,275$ \\
\hline & OTOKC & $-0,174$ & $-0,218$ & $-0,210$ & $-0,280$ & $-0,316$ & $-0,231$ & $-0,287$ & $-0,287$ \\
\hline & TOASO & $-0,353$ & $-0,319$ & $-0,330$ & $-0,239$ & $-0,342$ & $-0,333$ & $-0,303$ & $-0,256$ \\
\hline & TTRAK & $-0,215$ & $-0,207$ & $-0,202$ & $-0,220$ & $-0,158$ & $-0,138$ & $-0,157$ & $-0,180$ \\
\hline & \multicolumn{9}{|l|}{$\ln (8)=0,481$} \\
\hline & $e_{j}$ & 0,828 & 0,829 & 0,813 & 0,955 & 0,858 & 0,748 & 0,857 & 0,990 \\
\hline \multirow{7}{*}{2020} & İşletmeler /Kriterler & K1 & K2 & K3 & K4 & K5 & K6 & K7 & K8 \\
\hline & ASUZU & $-0,042$ & $-0,038$ & $-0,066$ & $-0,152$ & $-0,091$ & $-0,048$ & $-0,139$ & $-0,265$ \\
\hline & DOAS & $-0,312$ & $-0,289$ & $-0,211$ & $-0,182$ & $-0,217$ & $-0,293$ & $-0,310$ & $-0,260$ \\
\hline & FROTO & $-0,332$ & $-0,324$ & $-0,269$ & $-0,211$ & $-0,363$ & $-0,365$ & $-0,341$ & $-0,267$ \\
\hline & KARSN & $-0,042$ & $-0,044$ & $-0,080$ & $-0,361$ & $-0,116$ & $-0,057$ & $-0,039$ & $-0,271$ \\
\hline & OTKAR & $-0,308$ & $-0,327$ & $-0,367$ & $-0,317$ & $-0,160$ & $-0,091$ & $-0,237$ & $-0,277$ \\
\hline & OTOKC & $-0,190$ & $-0,226$ & $-0,218$ & $-0,226$ & $-0,309$ & $-0,255$ & $-0,282$ & $-0,282$ \\
\hline
\end{tabular}




\begin{tabular}{|l|l|l|l|l|l|l|l|l|l|}
\hline TOASO & $-0,249$ & $-0,271$ & $-0,254$ & $-0,197$ & $-0,345$ & $-0,322$ & $-0,322$ & $-0,278$ \\
\cline { 2 - 9 } & TTRAK & $-0,330$ & $-0,311$ & $-0,320$ & $-0,267$ & $-0,166$ & $-0,155$ & $-0,196$ & $-0,140$ \\
\cline { 2 - 3 } & $\ln (8)=0,481$ & 0,867 & 0,880 & 0,858 & 0,920 & 0,850 & 0,763 & 0,897 & 0,981 \\
\hline
\end{tabular}

Son olarak yıllar itibariyle entropi dereceleri ve kriter ağılıkları hesaplanmış ve Tablo 8'de gösterilmiştir.

Tablo 8. Entropi Dereceleri $\left(d_{j}\right)$ ve Karar Kriteri Ağırlıkları $\left(w_{j}\right)$

\begin{tabular}{|l|l|l|l|l|l|l|l|l|l|}
\hline & Derece ve Ağılıklar/Kriterler & K1 & K2 & K3 & K4 & K5 & K6 & K7 & K8 \\
\hline \multirow{2}{*}{2018} & $d_{j}$ & 0,083 & 0,096 & 0,074 & 0,055 & 0,127 & 0,244 & 0,143 & 0,008 \\
\cline { 2 - 10 } & $w_{j}$ & 0,100 & 0,116 & 0,089 & 0,066 & 0,153 & 0,294 & 0,173 & 0,010 \\
\hline \multirow{2}{*}{2019} & $d_{j}$ & & & & & & & & \\
\cline { 2 - 11 } & $w_{j}$ & 0,172 & 0,171 & 0,187 & 0,045 & 0,142 & 0,252 & 0,143 & 0,010 \\
\hline \multirow{2}{*}{2020} & $d_{j}$ & 0,153 & 0,152 & 0,166 & 0,040 & 0,126 & 0,225 & 0,127 & 0,009 \\
\cline { 2 - 10 } & $w_{j}$ & 0,133 & 0,120 & 0,142 & 0,080 & 0,150 & 0,237 & 0,103 & 0,019 \\
\hline
\end{tabular}

Entropi yöntemi ile kriter ağırlıkları belirlendikten sonra çalışma kapsamındaki işletmelerin performans sıralamalarını belirlemek için TOPSIS yöntemi kullanılacaktır. TOPSIS yönteminde ilk aşama karar matrisinin oluşturulması ve normalize edilerek standart karar matrisinin oluşturulmasıdır. Bu nedenle çalışmanın bu kısmında Tablo 4'teki karar matrisinin negatif değerlerden arındııılmıs düzeltilmiş karar matrisi olan Tablo 5'teki matris kullanılarak analize devam edilecektir. Düzeltilmiş karar matrisi öncelikle normalize edilecek daha sonra ise standart karar matrisine ulaşılacaktır. Normalize edilmiş karar matrisi Tablo 9'da ve standart karar matrisi ise Tablo 10' da belitilmiştir.

Tablo 9. TOPSIS Normalize Edilmiş Karar Matrisi

\begin{tabular}{|c|c|c|c|c|c|c|c|c|c|c|c|c|c|}
\hline & \multicolumn{5}{|c|}{$\begin{array}{l}\text { İşletmeler/ } \\
\text { Kriteriler }\end{array}$} & \multirow{2}{*}{$\begin{array}{r}\mathrm{K} 1 \\
0,010\end{array}$} & \multirow{2}{*}{$\begin{array}{l}\mathrm{K} 2 \\
0,010\end{array}$} & \multirow{2}{*}{$\begin{array}{l}\mathrm{K} 3 \\
0,010\end{array}$} & \multirow{2}{*}{$\begin{array}{l}\text { K4 } \\
0,001\end{array}$} & \multirow{2}{*}{$\begin{array}{l}\text { K5 } \\
2558928112225\end{array}$} & \multirow{2}{*}{$\begin{array}{l}\text { K6 } \\
1411016131044\end{array}$} & \multirow{2}{*}{$\begin{array}{l}\text { K7 } \\
20883140100\end{array}$} & \multirow{2}{*}{$\begin{array}{l}\text { K8 } \\
0,434\end{array}$} \\
\hline \multirow{8}{*}{$\begin{array}{l}2 \\
0 \\
1 \\
8\end{array}$} & A & & $S u$ & $\mathrm{~J} Z$ & & & & & & & & & \\
\hline & $\bar{D}$ & & 0 & $A$ & & 2,017 & 1,414 & 2,493 & 0,002 & 23027156990244 & 114243797103121 & 599735629476 & 0,529 \\
\hline & $\mathrm{F}$ & $\mathrm{F}$ & $\begin{array}{ll}\mathrm{R} & \mathrm{O} \\
\mathrm{R}\end{array}$ & $\mathrm{OT}$ & & 9,825 & 6,930 & 5,245 & 0,005 & 173829458113600 & 1108359261520900 & 1377566995204 & 0,496 \\
\hline & K & Tra & $A \quad R$ & $\mathrm{R} \quad \mathrm{S}$ & & 0,645 & 0,187 & 1,113 & 0,025 & 5569057213225 & 2078173078569 & 2748590329 & 0,741 \\
\hline & 0 & ) & $\mathrm{T}$ & A & & 4,728 & 6,679 & 10,048 & 0,019 & 5302639140516 & 2817902752921 & 129992697025 & 0,689 \\
\hline & $\mathrm{O}$ & & $T$ & $\mathrm{k}$ & & 3,418 & 4,224 & 5,772 & 0,013 & 64692487130896 & 56941482137764 & 327662366724 & 0,679 \\
\hline & $T$ & ( & $O A$ & $\mathrm{~s}$ & & 7,322 & 5,331 & 7,200 & 0,004 & 169046777236401 & 346083924295561 & 1784468505600 & 0,510 \\
\hline & $\mathrm{T}$ & 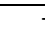 & T & A & K & 5,186 & 5,535 & 6,230 & 0,020 & 9568214122009 & 15279835377249 & 79305881769 & 0,193 \\
\hline \multirow{5}{*}{$\begin{array}{l}2 \\
0 \\
1 \\
9\end{array}$} & \multicolumn{5}{|c|}{ İşletmeler/Kriterler } & K1 & $\mathrm{K} 2$ & $\mathrm{~K} 3$ & K4 & K5 & K6 & K7 & K8 \\
\hline & A & & $S u$ & $U \quad Z$ & & 0,000 & 0,001 & 0,000 & 0,006 & 2485175685136 & 2024892002169 & 20816141284 & 0,412 \\
\hline & D & & 0 & $A$ & & 0,000 & 0,004 & 0,000 & 0,002 & 21761702523136 & 96906954521689 & 614030527201 & 0,534 \\
\hline & $\mathrm{F}$ & 1 & 0 & $\mathrm{~T}$ & & 0,006 & 0,176 & 0,002 & 0,004 & 269169042202384 & 1537347170942360 & 2538251189721 & 0,511 \\
\hline & $\mathrm{K}$ & 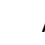 & A & $\mathrm{R}$ & $\mathrm{N}$ & 0,000 & 0,001 & 0,000 & 0,023 & 6215801908801 & 2904607812681 & 3276074169 & 0,564 \\
\hline
\end{tabular}




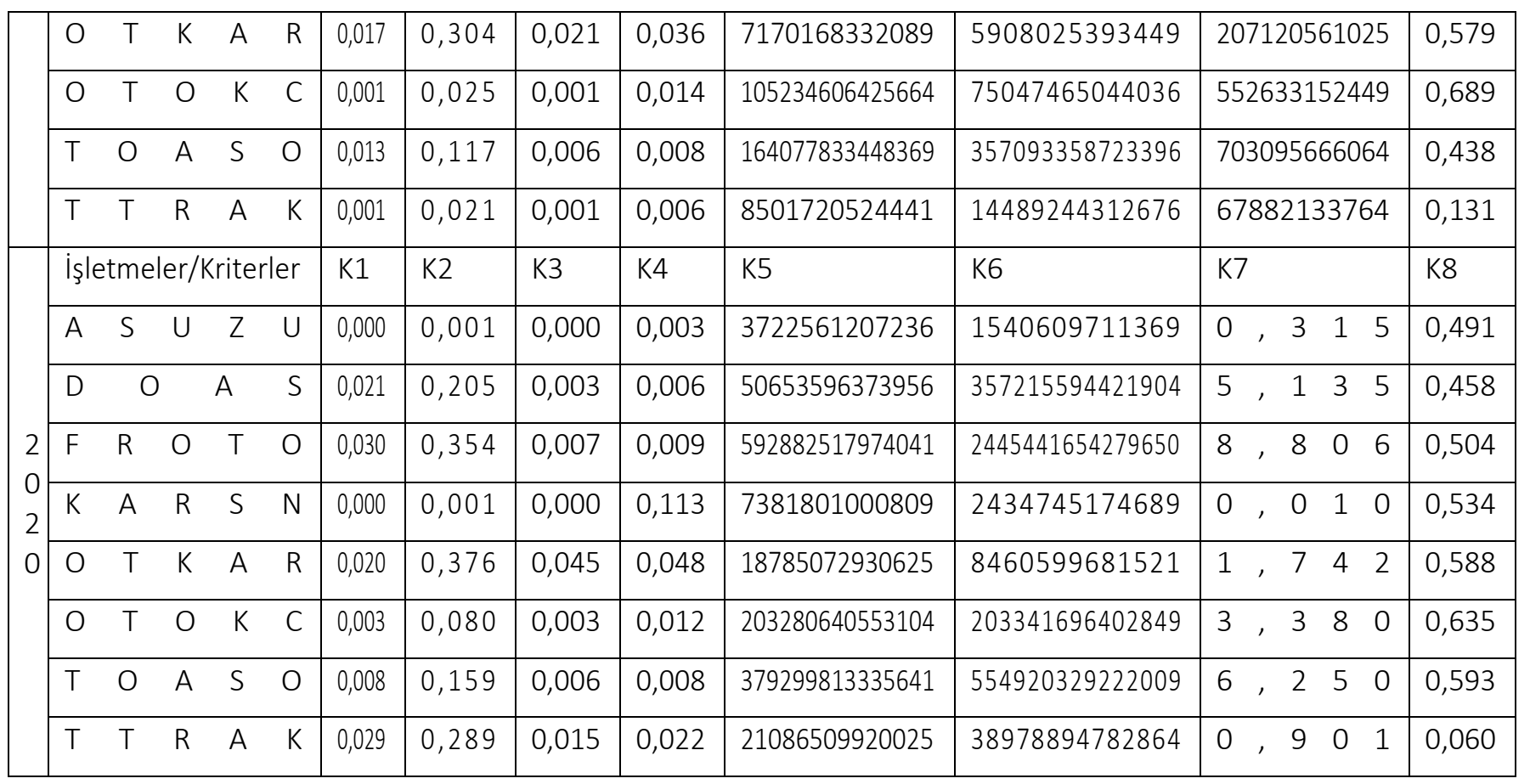

\section{Tablo 10. TOPSIS Standart Karar Matrisi}

\begin{tabular}{|c|c|c|c|c|c|c|c|c|c|}
\hline \multirow{9}{*}{2018} & İşletmeler/Kriterler & K1 & K2 & K3 & K4 & K5 & K6 & K7 & K8 \\
\hline & ASUZU & 0,017 & 0,018 & 0,016 & 0,111 & 0,075 & 0,029 & 0,070 & 0,319 \\
\hline & DOAS & 0,247 & 0,216 & 0,256 & 0,165 & 0,225 & 0,263 & 0,372 & 0,352 \\
\hline & FROTO & 0,544 & 0,478 & 0,371 & 0,229 & 0,619 & 0,820 & 0,565 & 0,341 \\
\hline & KARSN & 0,139 & 0,079 & 0,171 & 0,528 & 0,111 & 0,036 & 0,025 & 0,417 \\
\hline & OTKAR & 0,378 & 0,469 & 0,513 & 0,460 & 0,108 & 0,041 & 0,173 & 0,402 \\
\hline & OTOKC & 0,321 & 0,373 & 0,389 & 0,390 & 0,378 & 0,186 & 0,275 & 0,399 \\
\hline & TOASO & 0,470 & 0,419 & 0,435 & 0,212 & 0,610 & 0,458 & 0,643 & 0,346 \\
\hline & TTRAK & 0,396 & 0,427 & 0,404 & 0,470 & 0,145 & 0,096 & 0,135 & 0,212 \\
\hline \multirow{9}{*}{2019} & İşletmeler/Kriterler & K1 & K2 & K3 & K4 & K5 & K6 & K7 & K8 \\
\hline & ASUZU & 0,065 & 0,047 & 0,085 & 0,255 & 0,065 & 0,031 & 0,067 & 0,327 \\
\hline & DOAS & 0,081 & 0,076 & 0,039 & 0,156 & 0,193 & 0,215 & 0,361 & 0,372 \\
\hline & FROTO & 0,403 & 0,521 & 0,276 & 0,194 & 0,679 & 0,857 & 0,734 & 0,364 \\
\hline & KARSN & 0,040 & 0,040 & 0,062 & 0,481 & 0,103 & 0,037 & 0,026 & 0,382 \\
\hline & OTKAR & 0,660 & 0,684 & 0,812 & 0,605 & 0,111 & 0,053 & 0,210 & 0,387 \\
\hline & OTOKC & 0,136 & 0,197 & 0,175 & 0,376 & 0,424 & 0,189 & 0,343 & 0,423 \\
\hline & TOASO & 0,579 & 0,424 & 0,440 & 0,277 & 0,530 & 0,413 & 0,386 & 0,337 \\
\hline & TTRAK & 0,191 & 0,181 & 0,164 & 0,239 & 0,121 & 0,083 & 0,120 & 0,184 \\
\hline \multirow{4}{*}{2020} & İşletmeler/Kriterler & K1 & K2 & K3 & K4 & K5 & K6 & K7 & K8 \\
\hline & ASUZU & 0,021 & 0,019 & 0,035 & 0,123 & 0,054 & 0,021 & 0,109 & 0,357 \\
\hline & DOAS & 0,438 & 0,374 & 0,192 & 0,162 & 0,199 & 0,314 & 0,440 & 0,344 \\
\hline & FROTO & 0,516 & 0,492 & 0,298 & 0,207 & 0,681 & 0,823 & 0,576 & 0,361 \\
\hline
\end{tabular}




\begin{tabular}{|l|l|l|l|l|l|l|l|l|l|}
\hline & KARSN & 0,021 & 0,023 & 0,046 & 0,715 & 0,076 & 0,026 & 0,019 & 0,372 \\
\cline { 2 - 9 } & OTKAR & 0,426 & 0,506 & 0,752 & 0,464 & 0,121 & 0,048 & 0,256 & 0,390 \\
\cline { 2 - 5 } & 0,171 & 0,234 & 0,202 & 0,232 & 0,399 & 0,237 & 0,357 & 0,405 \\
\hline OTOKC & 0,273 & 0,330 & 0,266 & 0,185 & 0,545 & 0,392 & 0,485 & 0,392 \\
\hline
\end{tabular}

Elde edilen standart karar matrisi, entropi yöntemi ile bulunan kriter ağırlıkları ile ağırlıklandırılarak Tablo 11'deki ağırıklandırılmış karar matrisi elde edilmiştir.

Tablo 11. Ağırlıklandırılmış Standart Karar Matrisi

\begin{tabular}{|c|c|c|c|c|c|c|c|c|c|}
\hline \multirow{11}{*}{2018} & Kriter Ağırlıkları & 0,100 & 0,116 & 0,089 & 0,066 & 0,153 & 0,294 & 0,173 & 0,010 \\
\hline & Kriter Yönü & Maks & Maks & Maks & Maks & Maks & Maks & Min & Min \\
\hline & İşletmeler/Kriterler & K1 & K2 & K3 & K4 & K5 & K6 & K7 & K8 \\
\hline & ASUZU & 0,002 & 0,002 & 0,001 & 0,007 & 0,011 & 0,009 & 0,012 & 0,003 \\
\hline & DOAS & 0,025 & 0,025 & 0,023 & 0,011 & 0,034 & 0,077 & 0,064 & 0,004 \\
\hline & FROTO & 0,054 & 0,055 & 0,033 & 0,015 & 0,095 & 0,241 & 0,098 & 0,003 \\
\hline & KARSN & 0,014 & 0,009 & 0,015 & 0,035 & 0,017 & 0,010 & 0,004 & 0,004 \\
\hline & OTKAR & 0,038 & 0,054 & 0,046 & 0,030 & 0,017 & 0,012 & 0,030 & 0,004 \\
\hline & OTOKC & 0,032 & 0,043 & 0,035 & 0,026 & 0,058 & 0,055 & 0,048 & 0,004 \\
\hline & TOASO & 0,047 & 0,049 & 0,039 & 0,014 & 0,093 & 0,135 & 0,111 & 0,003 \\
\hline & TTRAK & 0,040 & 0,050 & 0,036 & 0,031 & 0,022 & 0,028 & 0,023 & 0,002 \\
\hline \multirow{11}{*}{2019} & Kriter Ağırlıkları & 0,153 & 0,152 & 0,166 & 0,040 & 0,126 & 0,225 & 0,127 & 0,009 \\
\hline & Kriter Yönü & Maks & Maks & Maks & Maks & Maks & Maks & Min & Min \\
\hline & İşletmeler/Kriterler & K1 & K2 & K3 & K4 & $\mathrm{K} 5$ & K6 & K7 & K8 \\
\hline & ASUZU & 0,010 & 0,007 & 0,014 & 0,010 & 0,008 & 0,007 & 0,008 & 0,003 \\
\hline & DOAS & 0,012 & 0,012 & 0,007 & 0,006 & 0,024 & 0,048 & 0,046 & 0,003 \\
\hline & FROTO & 0,062 & 0,079 & 0,046 & 0,008 & 0,085 & 0,193 & 0,093 & 0,003 \\
\hline & KARSN & 0,006 & 0,006 & 0,010 & 0,019 & 0,013 & 0,008 & 0,003 & 0,003 \\
\hline & OTKAR & 0,101 & 0,104 & 0,135 & 0,024 & 0,014 & 0,012 & 0,027 & 0,003 \\
\hline & OTOKC & 0,021 & 0,030 & 0,029 & 0,015 & 0,053 & 0,043 & 0,044 & 0,004 \\
\hline & TOASO & 0,089 & 0,064 & 0,073 & 0,011 & 0,067 & 0,093 & 0,049 & 0,003 \\
\hline & TTRAK & 0,029 & 0,028 & 0,027 & 0,010 & 0,015 & 0,019 & 0,015 & 0,002 \\
\hline \multirow{6}{*}{2020} & Kriter Ağırlıkları & 0,135 & 0,122 & 0,145 & 0,081 & 0,153 & 0,241 & 0,104 & 0,019 \\
\hline & Kriter Yönü & Maks & Maks & Maks & Maks & Maks & Maks & Min & Min \\
\hline & İşletmeler/Kriterler & K1 & $\mathrm{K} 2$ & K3 & K4 & $\mathrm{K} 5$ & K6 & K7 & K8 \\
\hline & ASUZU & 0,003 & 0,002 & 0,005 & 0,010 & 0,008 & 0,005 & 0,011 & 0,007 \\
\hline & DOAS & 0,059 & 0,046 & 0,028 & 0,013 & 0,030 & 0,076 & 0,046 & 0,007 \\
\hline & FROTO & 0,070 & 0,060 & 0,043 & 0,017 & 0,104 & 0,198 & 0,060 & 0,007 \\
\hline
\end{tabular}




\begin{tabular}{|l|l|l|l|l|l|l|l|l|l|}
\hline & KARSN & 0,003 & 0,003 & 0,007 & 0,058 & 0,012 & 0,006 & 0,002 & 0,007 \\
\cline { 2 - 9 } & OTKAR & 0,057 & 0,062 & 0,109 & 0,038 & 0,019 & 0,012 & 0,027 & 0,007 \\
\cline { 2 - 5 } & 0,023 & 0,029 & 0,029 & 0,019 & 0,061 & 0,057 & 0,037 & 0,008 \\
\hline TOASO & 0,037 & 0,040 & 0,039 & 0,015 & 0,083 & 0,094 & 0,050 & 0,007 \\
\hline TTRAK & 0,068 & 0,054 & 0,064 & 0,026 & 0,020 & 0,025 & 0,019 & 0,002 \\
\hline
\end{tabular}

Ağırlıklandırılan standart karar matrisinden sonra her bir kriter için pozitif ve negatif ideal çözüm değerleri hesaplanır. Pozitif ve negatif ideal çözüm değerleri Tablo 12'de gösterilmiştir.

Tablo 12. Pozitif ve Negatif İdeal Çözüm Değerleri

\begin{tabular}{|l|l|l|l|l|l|l|l|l|l|}
\hline \multirow{3}{*}{2018} & K1 & K2 & K3 & K4 & K5 & K6 & K7 & K8 \\
\cline { 2 - 9 } & Pozitif İdeal Çözüm & 0,054 & 0,055 & 0,046 & 0,035 & 0,095 & 0,241 & 0,004 & 0,002 \\
\cline { 2 - 10 } & Negatif Ideal Çözüm & 0,002 & 0,002 & 0,001 & 0,007 & 0,011 & 0,009 & 0,111 & 0,004 \\
\hline \multirow{3}{*}{2019} & & K1 & K2 & K3 & K4 & K5 & K6 & K7 & K8 \\
\cline { 2 - 10 } & Pozitif İdeal Çözüm & 0,101 & 0,104 & 0,135 & 0,024 & 0,085 & 0,193 & 0,003 & 0,002 \\
\cline { 2 - 9 } & Negatif İdeal Çözüm & 0,006 & 0,006 & 0,007 & 0,006 & 0,008 & 0,007 & 0,093 & 0,004 \\
\hline \multirow{3}{*}{2020} & & K1 & K2 & K3 & K4 & K5 & K6 & K7 & K8 \\
\cline { 2 - 9 } & Pozitif İdeal Çözüm & 0,070 & 0,062 & 0,109 & 0,058 & 0,104 & 0,198 & 0,002 & 0,002 \\
\cline { 2 - 9 } & Negatif İdeal Çözüm & 0,003 & 0,002 & 0,005 & 0,010 & 0,008 & 0,005 & 0,060 & 0,008 \\
\hline
\end{tabular}

Tablo 13 ve Tablo 14'te her bir alternatifin kriter değerlerinin pozitif ve negatif ideal noktalara uzaklıkları gösterilmiştir.

\section{Tablo 13. Pozitif Ideal Noktalara Uzaklık}

\begin{tabular}{|c|c|c|c|c|c|c|c|c|c|c|c|}
\hline \multirow{9}{*}{2018} & İşletmeler/Kriterler & K 1 & K 2 & $\mathrm{~K}$ & K 4 & $K$ & 6 & $K$ & K & Toplam & $\mathrm{S} ;{ }^{*}$ \\
\hline & ASUZU & 0,003 & 0,003 & 0,002 & 0,001 & 0,007 & 0,054 & 0,000 & 0,000 & 0,069 & 0,263 \\
\hline & DOAS & 0,001 & 0,001 & 0,001 & 0,001 & 0,004 & 0,027 & 0,004 & 0,000 & 0,037 & 0,192 \\
\hline & FROTO & 0,000 & 0,000 & 0,000 & 0,000 & 0,000 & 0,000 & 0,009 & 0,000 & 0,009 & 0,096 \\
\hline & KARSN & 0,002 & 0,002 & 0,001 & 0,000 & 0,006 & 0,053 & 0,000 & 0,000 & 0,064 & 0,253 \\
\hline & OTKAR & 0,000 & 0,000 & 0,000 & 0,000 & 0,006 & 0,052 & 0,001 & 0,000 & 0,060 & 0,244 \\
\hline & OTOKC & 0,000 & 0,000 & 0,000 & 0,000 & 0,001 & 0,035 & 0,002 & 0,000 & 0,039 & 0,197 \\
\hline & TOASO & 0,000 & 0,000 & 0,000 & 0,000 & 0,000 & 0,011 & 0,011 & 0,000 & 0,023 & 0,153 \\
\hline & TTRAK & 0,000 & 0,000 & 0,000 & 0,000 & 0,005 & 0,045 & 0,000 & 0,000 & 0,051 & 0,226 \\
\hline \multirow{7}{*}{2019} & İşletmeler/Kriterler & K 1 & K 2 & K 3 & K 4 & K 5 & K 6 & $\mathrm{~K}$ & K & Toplam & $\mathrm{S}_{\mathrm{i}} *$ \\
\hline & ASUZU & 0,008 & 0,009 & 0,015 & 0,000 & 0,006 & 0,035 & 0,000 & 0,000 & 0,073 & 0,270 \\
\hline & DOAS & 0,008 & 0,009 & 0,016 & 0,000 & 0,004 & 0,021 & 0,002 & 0,000 & 0,060 & 0,244 \\
\hline & FROTO & 0,002 & 0,001 & 0,008 & 0,000 & 0,000 & 0,000 & 0,008 & 0,000 & 0,018 & 0,136 \\
\hline & KARSN & 0,009 & 0,010 & 0,016 & 0,000 & 0,005 & 0,034 & 0,000 & 0,000 & 0,073 & 0,271 \\
\hline & OTKAR & 0,000 & 0,000 & 0,000 & 0,000 & 0,005 & 0,033 & 0,001 & 0,000 & 0,038 & 0,196 \\
\hline & ОTOKC & 0,006 & 0,005 & 0,011 & 0,000 & 0,001 & 0,023 & 0,002 & 0,000 & 0,048 & 0,220 \\
\hline
\end{tabular}




\begin{tabular}{|c|c|c|c|c|c|c|c|c|c|c|c|}
\hline & TOASO & 0,000 & 0,002 & 0,004 & 0,000 & 0,000 & 0,010 & 0,002 & 0,000 & 0,018 & 0,135 \\
\hline & TTRAK & 0,005 & 0,006 & 0,012 & 0,000 & 0,005 & 0,030 & 0,000 & 0,000 & 0,058 & 0,241 \\
\hline \multirow{9}{*}{2020} & İşletmeler/Kriterler & K 1 & K 2 & K 3 & K 4 & K 5 & K 6 & $K$ & K 8 & Toplam & $\mathrm{S} ; *$ \\
\hline & ASUZU & 0,004 & 0,004 & 0,011 & 0,002 & 0,009 & 0,037 & 0,000 & 0,000 & 0,068 & 0,260 \\
\hline & DOAS & 0,000 & 0,000 & 0,007 & 0,002 & 0,005 & 0,015 & 0,002 & 0,000 & 0,031 & 0,177 \\
\hline & FROTO & 0,000 & 0,000 & 0,004 & 0,002 & 0,000 & 0,000 & 0,003 & 0,000 & 0,009 & 0,097 \\
\hline & KARSN & 0,004 & 0,003 & 0,010 & 0,000 & 0,009 & 0,037 & 0,000 & 0,000 & 0,064 & 0,253 \\
\hline & OTKAR & 0,000 & 0,000 & 0,000 & 0,000 & 0,007 & 0,035 & 0,001 & 0,000 & 0,043 & 0,208 \\
\hline & OTOKC & 0,002 & 0,001 & 0,006 & 0,002 & 0,002 & 0,020 & 0,001 & 0,000 & 0,034 & 0,185 \\
\hline & TOASO & 0,001 & 0,000 & 0,005 & 0,002 & 0,000 & 0,011 & 0,002 & 0,000 & 0,022 & 0,148 \\
\hline & TTRAK & 0,000 & 0,000 & 0,002 & 0,001 & 0,007 & 0,030 & 0,000 & 0,000 & 0,041 & 0,202 \\
\hline
\end{tabular}

Tablo 14. Negatif İdeal Noktalara Uzaklık

\begin{tabular}{|c|c|c|c|c|c|c|c|c|c|c|c|}
\hline \multirow{9}{*}{2018} & İşletmeler/Kriterler & K 1 & K 2 & K 3 & K 4 & K 5 & K 6 & K & K 8 & Toplam & $S i^{-}$ \\
\hline & ASUZU & 0,000 & 0,000 & 0,000 & 0,000 & 0,000 & 0,000 & 0,010 & 0,000 & 0,010 & 0,099 \\
\hline & DOAS & 0,001 & 0,001 & 0,000 & 0,000 & 0,001 & 0,005 & 0,002 & 0,000 & 0,009 & 0,095 \\
\hline & FROTO & 0,003 & 0,003 & 0,001 & 0,000 & 0,007 & 0,054 & 0,000 & 0,000 & 0,068 & 0,261 \\
\hline & KARSN & 0,000 & 0,000 & 0,000 & 0,001 & 0,000 & 0,000 & 0,011 & 0,000 & 0,013 & 0,112 \\
\hline & OTKAR & 0,001 & 0,003 & 0,002 & 0,001 & 0,000 & 0,000 & 0,007 & 0,000 & 0,013 & 0,115 \\
\hline & ОTOKC & 0,001 & 0,002 & 0,001 & 0,000 & 0,002 & 0,002 & 0,004 & 0,000 & 0,012 & 0,111 \\
\hline & TOASO & 0,002 & 0,002 & 0,001 & 0,000 & 0,007 & 0,016 & 0,000 & 0,000 & 0,028 & 0,168 \\
\hline & TTRAK & 0,001 & 0,002 & 0,001 & 0,001 & 0,000 & 0,000 & 0,008 & 0,000 & 0,014 & 0,117 \\
\hline \multirow{9}{*}{2019} & İşletmeler/Kriterler & K 1 & K & & & K 5 & K 6 & K & K 8 & Toplam & $S_{i}-$ \\
\hline & ASUZU & 0,000 & 0,000 & 0,000 & 0,000 & 0,000 & 0,000 & 0,007 & 0,000 & 0,007 & 0,085 \\
\hline & DOAS & 0,000 & 0,000 & 0,000 & 0,000 & 0,000 & 0,002 & 0,002 & 0,000 & 0,004 & 0,065 \\
\hline & FROTO & 0,003 & 0,005 & 0,002 & 0,000 & 0,006 & 0,035 & 0,000 & 0,000 & 0,051 & 0,225 \\
\hline & KARSN & 0,000 & 0,000 & 0,000 & 0,000 & 0,000 & 0,000 & 0,008 & 0,000 & 0,008 & 0,091 \\
\hline & OTKAR & 0,009 & 0,010 & 0,016 & 0,000 & 0,000 & 0,000 & 0,004 & 0,000 & 0,040 & 0,200 \\
\hline & OTOKC & 0,000 & 0,001 & 0,001 & 0,000 & 0,002 & 0,001 & 0,002 & 0,000 & 0,007 & 0,085 \\
\hline & TOASO & 0,007 & 0,003 & 0,004 & 0,000 & 0,003 & 0,007 & 0,002 & 0,000 & 0,027 & 0,166 \\
\hline & TTRAK & 0,001 & 0,000 & 0,000 & 0,000 & 0,000 & 0,000 & 0,006 & 0,000 & 0,008 & 0,088 \\
\hline \multirow{6}{*}{2020} & İşletmeler/Kriterler & K 1 & K 2 & K 3 & K 4 & K 5 & K 6 & & K & Toplam & $S i^{-}$ \\
\hline & ASUZU & 0,000 & 0,000 & 0,000 & 0,000 & 0,000 & 0,000 & 0,002 & 0,000 & 0,002 & 0,049 \\
\hline & DOAS & 0,003 & 0,002 & 0,001 & 0,000 & 0,000 & 0,005 & 0,000 & 0,000 & 0,011 & 0,106 \\
\hline & FROTO & 0,004 & 0,003 & 0,001 & 0,000 & 0,009 & 0,037 & 0,000 & 0,000 & 0,056 & 0,236 \\
\hline & KARSN & 0,000 & 0,000 & 0,000 & 0,002 & 0,000 & 0,000 & 0,003 & 0,000 & 0,006 & 0,075 \\
\hline & OTKAR & 0,003 & 0,004 & 0,011 & 0,001 & 0,000 & 0,000 & 0,001 & 0,000 & 0,019 & 0,139 \\
\hline
\end{tabular}




\begin{tabular}{|l|l|l|l|l|l|l|l|l|l|l|l|}
\hline & OTOKC & 0,000 & 0,001 & 0,001 & 0,000 & 0,003 & 0,003 & 0,001 & 0,000 & 0,008 & 0,088 \\
\cline { 2 - 5 } & 0,001 & 0,001 & 0,001 & 0,000 & 0,006 & 0,008 & 0,000 & 0,000 & 0,017 & 0,132 \\
\cline { 2 - 8 } & TTRAK & 0,004 & 0,003 & 0,003 & 0,000 & 0,000 & 0,000 & 0,002 & 0,000 & 0,013 & 0,114 \\
\hline
\end{tabular}

En son olarak da yıllar itibariyle alternatiflerin performans değerleri hesaplanmış ve bu değerlere göre işletmelerin performans sıralamaları elde edilmiştir. Performans değerleri ve performans sıralamaları Tablo 15 'te gösterilmiştir.

Tablo 15. Performans Değerleri ve Sıralamalar

\begin{tabular}{|l|l|l|l|l|l|l|l|l|}
\hline \multicolumn{3}{|c|}{2018} & \multicolumn{3}{c|}{2019} & \multicolumn{3}{c|}{2020} \\
\hline & $C_{i}{ }^{*}$ & SIralama & & $C_{i}{ }^{*}$ & Siralama & & $C_{i}{ }^{*}$ & Siralama \\
\hline ASUZU & 0,273 & 8 & ASUZU & 0,240 & 7 & ASUZU & 0,157 & 8 \\
\hline DOAS & 0,330 & 5 & DOAS & 0,212 & 8 & DOAS & 0,375 & 4 \\
\hline FROTO & 0,730 & 1 & FROTO & 0,623 & 1 & FROTO & 0,709 & 1 \\
\hline KARSN & 0,307 & 7 & KARSN & 0,252 & 6 & KARSN & 0,229 & 7 \\
\hline OTKAR & 0,320 & 6 & OTKAR & 0,505 & 3 & OTKAR & 0,400 & 3 \\
\hline OTOKC & 0,361 & 3 & OTOKC & 0,278 & 4 & OTOKC & 0,323 & 6 \\
\hline TOASO & 0,524 & 2 & TOASO & 0,552 & 2 & TOASO & 0,472 & 2 \\
\hline TTRAK & 0,340 & 4 & TTRAK & 0,267 & 5 & TTRAK & 0,360 & 5 \\
\hline
\end{tabular}

\section{Sonuç ve Değerlendirme}

Kotler'e göre (1991: 442) marka, bir satıcının veya satıcı grubunun mal ve hizmetlerini tanımlamayı ve onları, rakiplerin mal ve hizmetlerinden farklılaştırmayı amaçlayan bir isim, terim, işaret, sembol ya da bunların birleşimidir. Maddi olmayan duran varlıklar bağlamında ele alınan markalar, özellikle son yıllarda, işletme değerinin önemli belirleyicileri arasında üst sıralarda yer almaktadır. Bir markanın satış değerini ifade eden marka değeri kavramı ise, markanın farklılaşmasını ve üstün rekabet gücü elde etmesini sağlayan aynı zamanda operasyonel olarak da verimliliği artıran bir tür kaldıraç görevi üstlenmektedir. Pazarlama yöneticileri için marka değerini başarıyla tespit etmek; karar verme sürecini kolaylaştıran, yeni mal ve hizmetlerin üretimini teşvik eden, yapılan faaliyetlere yön veren, markaya olan bağlıı̆ı artıran stratejik bir konu olarak ele alınmaktadır. Bu sebeple marka değeri yaratmanın ve başarı ile sunmanın potansiyelini fark eden pek çok pazarlama yöneticisi, marka değerinin başarı ile ölçülmesine yönelik önemli çabalar sarf etmektedir. Bu bağlamda marka değerinin artan önemi, farklı değerleme yöntemlerin kullanılmasını da beraberinde getirmektedir. Bugün pek çok işletme marka değerlerini hesaplamak adına çeşitli yöntemlerden faydalanmaktadır. En çok kullanılan yöntemler arasında; pazar temelli yaklaşım, maliyet temelli yaklaşım, gelire dayalı yaklaşım ve formüler yaklaşım yer almaktadır.

Çalışmada 2018, 2019 ve 2020 yıllarında Brand Finance Türkiye 100 sıralamasına giren otomotiv sektörü kuruluşlarının marka değeri sıralaması ile performans sıralamaları karşılıklı olarak analiz edilmiştir. Marka değeri sıralamaları için yıllık olarak yayınlanan Brand Finance Türkiye 100 raporlarından yararlanılmıştır. Performans sıralamaları için aynı işletmelerden Borsa İstanbul'da işlem gören işletmelerin ilgili tablolarından elde edilen veriler karar kriteri olarak kullanılmıştır. Performans odaklı karar kriterlerinin ağırlıkları entropi yöntemi kullanılarak belirlenirken, belirlenen bu ağırlıklar ile TOPSIS yöntemi kullanılarak performans sıralamalarına ulaşılmıştır.

Yapılan analiz ve araştırmalar sonucunda otomotiv sektöründe 2018 yılında Brand Finance Türkiye 100 sıralamasında en başta yer alan işletme 458 milyon dolarlık marka değeri ile Ford Otomotiv, ikinci sırada 299 milyon dolarlık marka değeri ile Tofaş ve üçüncü sırada ise 186 milyon dolarlık marka değeri ile Doğuş Otomotiv'dir. 2019 ve 2020 yıllarında da marka değerleri sıralamasında ilk üçte yer alan işletmeler değişmemektedir. 2018, 2019 ve 2020 yıllarında marka değeri en düşük işletmelerin sırasıyla Otokoç, Otokoç ve Anadolu Isuzu olduğu görülmektedir.

Entropi temelli TOPSIS yöntemi ile yapılan analiz sonunda 2018 yılında en yüksek performans gösteren ilk üç işletme sırasıyla; Ford Otomotiv, Tofaş ve Otokoç olarak sıralanmaktadır. 2019 yıında performans sıralamasında ilk iki 
sırada yine Ford Otomotiv ve Tofaş yer alırken en iyi performans gösteren üçüncü işletme, Otokar olarak belirlenmiştir. 2020 yılında ise performans sıralaması 2019 sıralaması ile aynı şekilde Ford Otomotiv, Tofaş ve Otokar olarak sıralanmıştır. En düşük performans gösteren işletmeler ise 2018, 2019 ve 2020 yılları için sırasıyla Anadolu Isuzu, Doğuş Otomotiv ve Anadolu Isuzu olarak gerçekleşmiştir. Performans sıralamasında karar kriterlerinin ağırlıkları etkili olmaktadır. Bu çalışmada karar kriterlerinden net satışlar (K6) kriteri, karar kriteri ağılıkları içinde her üç yılda da en yüksek ağıllığa sahip olduğu görülmektedir. Bu nedenle bütün kriterler içinde performansa etki eden en önemli kriter net satışlar olarak öne çıkmaktadır. Bir işletmenin net satışları ne kadar yüksekse, performansının da o derece yüksek olduğu söylenebilmektedir.

Yıllar itibariye Brand Finance Türkiye 100 marka değeri sıralaması ile performans sıralamaları karşılıklı olarak incelendiğinde çalışmaya konu olan her üç yılda aynı işletmelerin marka değeri olarak ilk üç sırada yer aldığı görülmektedir. Bu işletmelerin performansları incelendiğinde de her üç yılda ilk iki sıradaki işletmelerin marka değeri en yüksek iki işletme olduğu tespit edilmiştir. Bu karşılaştırmada dikkat çeken bir nokta da performans olarak 2018 yılında üçüncü sırada ve 2019 yılında dördüncü sırada yer alan Otokoç işletmesinin, ilgili yıllarda marka değeri sıralamasında ilk 100'de giremediğidir. Aynı zamanda 2019 yılında marka değeri olarak üçüncü sırada yer alan Doğuş Otomotiv işletmesi ise ilgili yılda en düşük performansa sahip işletme olarak karşımıza çıkmaktadır. Bu karşılaştırmalar sonucunda performansa etki eden en önemli karar kriterinin, net satışlar olduğu da düşünülürse işletmelerin öncelikle satış performanslarını artırmaları ve bu sayede de performanslarının yanı sıra marka değerlerinin de yukarıya taşınacağı yorumu yapılabilmektedir. Yapılan bu çalışma, otomotiv sektörü özelinde marka değeri ve performansın birlikte kullanıldığı ilk çalışma olması açısından literatüre katkı sağlamaktadır.

Gelecekte yapılması muhtemel çalışmalar için araştırmacılara, farklı sektörlerde marka değeri ve performans sıralamaları yapmaları önerilmektedir. Aynı zamanda, marka değeri hesaplamada, diğer yöntemler kullanılarak da analizler yapılması tavsiye edilmektedir. Ayrıca otomotiv sektörü özelinde de işletmelerin karar kriter sayılarının artırılması ve farklı yöntemlerle de performans analizi yapılarak değerlendirme yapılması ve tüm bunlarla birlikte; yapılacak çalışmalar sonucu elde edilecek bulguların karşılaştırmalı olarak analize tabi tutulmaları, diğer öneriler arasında sayılmaktadır.

\section{Kaynakça}

Aaker, D. A. (2003). Brand Building. Czech Republic: Computer Press.

Akçakanat, Ö., Eren, H., Aksoy, E. \& Ömürbek, V. (2017). Bankacılık sektöründe entropi ve waspas yöntemleri ile performans değerlendirmesi. Süleyman Demirel Üniversitesi iktisadi ve Idari Bilimler Fakültesi Dergisi, 22(2), 285300.

Alemdar, Y. M. \& Dirik, Ç. (2016). Tüketici temelli marka denkliği. Ordu Üniversitesi Sosyal Bilimler Araştırmaları Dergisi, 6(3), 821-838.

American Marketing Association. (2021). Definition of Brand. Erişim Adresi: https://www.ama.org/the-definition-ofmarketing-what-is-marketing/. Erişim Tarihi: 10.07.2021.

Apan, M. (2020). Bankaların marka değeri performansları ile finansal performanslarının karşılaştırmalı analizi: Türk mevduat bankaları üzerine bir uygulama. Iğdır Üniversitesi Sosyal Bilimler Dergisi, 22, 487-518.

Ayçin, E. (2019). Çok Kriterli Karar Verme Bilgisayar Uygulamalı Çözümler. Ankara: Nobel Yayınevi.

Barwise, P., Higson, C., Likierman, A. \& Marsh, P. (1990). Brands as separable assets. Business Strategy Review, 1(2), 4359.

Baydaş, A. (2011). Marka değeri ve marka sadakatinin GSM operatörleri bağlamında incelenmesi. Bingöl Üniversitesi iktisadi ve Idari Bilimler Fakültesi Dergisi, 2(2), 11-36.

Brand Finance. (2021). Automotive Industry 2021 Ranking, Erişim Adresi: https://brandirectory.com/rankings/auto/table. Erişim Tarihi: 25.06.2021.

Brand Finance. (2021). Global 5002021 Ranking, Erişim Adresi: https://brandirectory.com/rankings/global/table. Erişim Tarihi: 25.06.2021.

Brand Finance. (2021). Marka Değerleme Yöntemi. Erişim adresi: https://brandirectory.com/download-report/brandfinance-turkey-100-2021-full-report.pdf. Erişim Tarihi: 26.06.2021. 
Brand Finance. (2021). Turkey 1002021 Ranking, Erişim Adresi: https://brandirectory.com/rankings/turkey/table. Erişim Tarihi: 25.06.2021.

Bulgurcu, B. (2013). Financial Performance ranking of the automotive Industry firms in Turkey: Evidence from an entropy-weighted technique. International Journal of Economics and Financial Issues, 3(4), 844-851.

Chen, C. T. (2000). Extensions of the TOPSIS for group decision-making under fuzzy environment. Fuzzy Sets and Systems, 114(1), 1-9.

Cravens, K. S., \& C. Guilding. (1999). Strategic brand valuation: A cross-functional perspective. Business Horizons, 42(4), $53-4$.

Çanakçığlu, M. \& Küçükönder, H. (2020). Entropi ve Topsis bütünleşik yaklaşımı ile bıst gıda ve içecek endeksindeki şirketlerin finansal performanslarının değerlendirilmesi. Gümüşhane Üniversitesi Sosyal Bilimler Enstitüsü Elektronik Dergisi, 11(2), 200-217.

Değer, A. \& Aydoğan, E. (2017). Finansal bazlı marka değerinin firma performansı üzerine etkisi. International Journal of Academic Value Studies, 3(16), 141-155.

Deng H., Yeh, C.H. \& Willis R.J. (2000). Inter-company comparison using modified TOPSIS with objective weights. Computers \& Operations Research, 27(10), 963-973.

Ecer, F. (2020). Çok Kriterli Karar Verme. Ankara: Seçkin Yayıncılık.

Erol, I. \& Ferrell Jr, W. G. (2009). Integrated approach for reorganizing purchasing: Theory and a case analysis on a Turkish company. Computers \& Industrial Engineering, 56(4), 1192-1204.

Esmer, Y. \& Dayı, F. (2019). Stratejik performans yönetiminde finansal performans değerlemesi: bıst otomotiv sektöründe bir uygulama. Selçuk Üniversitesi Sosyal Bilimler MYO Dergisi, 22(2), 628-645.

Gajanova L., Nadanyiova M., Majerova J. and Aljarah A. (2021). Brand value sources in bankıng industry: evidence for marketıng communıcatıon across generatıonal cohorts, polish. Journal of Management Studies, 23(1), 151-171.

Hertioga, C. \& Christensen, J. (2021). What Is A Brand. Erişim Adresi: https://www.interbrand.com/london/thinking/what-is-a-brand/. Erişim Tarihi: 11.07.2021.

Hsu, F. J., Tsai, Y. W. \& Chen, M. Y. (2013). The Impact of brand value on financial performance. Advances in Management \& Applied Economics, 3(6),129-141.

Hwang, C. L., \& Yoon, K. (1981). Methods for Multiple Attribute Decision Making Multiple Attribute Decision Making. Berlin, Heidelberg: Springer.

Ignatius, J., Behzadian, M., Malekan, S.H. \& Lalitha, D. (2012). Financial performance of Iran's automotive sector based on promethee II. IEEE International Conference on Management of Innovation \& Technology (ICMIT), 35-38.

Kara, A. (2019). "Firma değeri yaratımında marka gücünün etkisi: Interbrand indirgenmiş nakit akışı yöntemiyle Türk markalarının analizi. Optimum Ekonomi ve Yönetim Bilimleri Dergisi. 6(2), 227-246.

Karakış, E. \& Göktolga, Z.G. (2015). Borsa İstanbul'da işlem gören otomotiv imalat sektörü firmalarının finansal performanslarının electre ve ahp yöntemleri ile analizi. C.Ü. iktisadi ve Idari Bilimler Dergisi, 16(2), 259-280.

Kayalı, C. A. \& Aktaş, İ. (2018). BisT’te Hisse senetleri işlem gören otomotiv sektöründeki firmaların topsis yöntemine göre performans değerlemesi ve analizi. Sosyal Bilimler Enstitüsü Dergisi, 8(1), 43-59.

Keller, K.L. (1993). Conceptualızıng, measurıng, and managing customer-based brand equity. Journal of Marketing, 57, $1-22$.

Keskin, I., \& Altan, Ş. (2020). TOPSIS Yöntemi. Ed. M. Atan ve ş. Altan, Örnek Uygulamalarla Çok Kriterli Karar Verme Yöntemleri, (ss. 69-81), Ankara: Gazi Kitabevi.

Kotler, P. H. (1991). Marketing Management: Analysis, Planning, and Control. 8th ed.: Englewood Cliffs, NJ: PrenticeHall, Inc.

Kucharska, W. (2016). Customer Assessment of Brand Valuation and Social Media. Eds. Bernadas, C. \& Minchella, D., Proceedings of the 3rd European Conference on Social Media, ACPI, (pp. 134-142). 
Kucharska, W., Flisikowski, K. \& Confente, I. (2018). Do global brands contribute to the economy of their country of origin? A dynamic spatial approach. Journal of Product \& Brand Management, 27(7), 768-780.

Lassar, W., Mittal, B. \& Sharma, A., (1995). Measuring customer-based brand equity. Journal of Consumer Marketing, 12(4), 11-19.

Lischer, B. (2021). What Is A Brand? Erişim Adresi: https://www.ignytebrands.com/what-is-a-brand/. Erişim Tarihi: 26.06.2021.

Mathur, S. ve Agarwal, K. (2016). Financial analysis of automobile Industries (A comparative study of Tata Motors and Maruti Suzuki). International Journal of Applied Research, 2(9), 533-539.

Mishra, S. (2016). Brand valuation: Accounting perspective. Global Journal of Enterprise Information System, 8(4), 4247.

Moradi M. \& Janatifar H. (2014). Performance evaluation of automobile companies based on multi-criteria decision making techniques. Global Journal of Management Studies and Researches, 1(2), 77- 84

Nam, E.K. (2010). Marka değeri hesaplama tekniklerinin incelenmesi ve uygulamalı olarak karşılaştırılması. (Yayımlanmamış yüksek lisans tezi). Gazi Üniversitesi, Sosyal Bilimler Enstitüsü, İ̧̧letme Anabilim Dalı. Ankara.

Organ, A. \& Kaçaroğlu, M. O. (2020). Entropi ağırlıklı topsıs yöntemi ile Türkiye'deki vakıf üniversitelerinin değerlendirilmesi. Pamukkale İşletme ve Bilişim Yönetimi Dergisi, 7(1), 28-45.

Ömürbek, N. \& Balcı, H. (2017). Entropi temelli copras yöntemi ile Avrupa birliği ülkeleri ve Türkiye'nin havayolu taşımacılığının değerlendirilmesi. Süleyman Demirel Üniversitesi Vizyoner Dergisi, 8 (18), 13-25.

Ömürbek, N., Karaatlı M., \& Balcı H. F. (2016). Entropi temelli maut ve saw yöntemleri ile otomotiv firmalarının performans değerlemesi. Dokuz Eylül Üniversitesi Iktisadi ve Idari Bilimler Fakültesi Dergisi, 31(1), 227-255

Özdağoğlu, A., Yakut, E. \& Bahar, S. (2017). Machine selection in a dairy product company with entropy and saw method Integration. Dokuz Eylül Üniversitesi Iktisadi ve Idari Bilimler Fakültesi Dergisi, 32(1), 341-359.

Özkan, T. (2020). Türk bankacılık sektöründe finansal performans ölçmede topsıs yönteminin kullanımı: Katılım bankaları üzerine bir uygulama. Maliye ve Finans Yazıları, 113, 47-64.

Parment, A. (2008). Distribution Strategies for volume and premium brands in highly competitive consumer markets. Journal of Retailing and Consumer Services, 15(4), 250-265.

Perçin, S. \& Sönmez, Ö. (2018). Bütünleşik entropi ağırlık ve topsıs yöntemleri kullanılarak Türk sigorta şirketlerinin performansının ölçülmesi. Uluslararası iktisadi ve Idari Incelemeler Dergisi, 18. EYi Özel Sayısı, 565-582.

Polat, Ç. \& Peker, K.Ö. (2016). Makro ekonomik değişkenlerin firma performansına etkileri: Türkiye otomotiv sektörü kapsamında analizi. Eskişsehir Osmangazi Üniversitesi Sosyal Bilimler Dergisi, 17(1), 21-60.

Sakarya, Ş. \& Aksu, M. (2020). Ulaşım sektöründeki işletmelerin finansal performanslarının geliştirilmiş entropi temelli topsıs yöntemi ile değerlendirilmesi. Optimum Ekonomi ve Yönetim Bilimleri Dergisi, 7(1), 21-40.

Seetharaman, A., Z. Azlan Bin Mohd Nadzir, \& S. Gunalan. (2001). A conceptual study on brand valuation. Journal of Product \& Brand Management, 10 (4), 243-56.

Shemshadi A., Shirazi H., Toreihi M. \& Tarokh M.J. (2011). A fuzzy vıkor method for supplier selection based on entropy measure for objective weighting. Expert Systems with Applications, 38, 12160-12167.

Simon, J.C. \& Sullivan, W.M. (1993). The Measurement and determinants of brand equity: a financial approach. Marketing Science, 12(1), 28-52.

Skalický, R., Meluzín, T., \& Zinecker, M. (2021). Brand valuation: An ınnovative approach based on the risk difference. Oeconomia Copernicana, 12(1), 159-191.

Srivastava, R.K., Fahey, L. \& Shervani, T.A. (1998). Marketing, business processes, and shareholder value: an organizationally embedded view of marketing activities and the discipline of marketing. Journal of Marketing, 63, 168-179. 
Svetlik, J., \& Vavrecka, V., (2016). Word of Mouse in the World of Brands. Eds. D. Petranova, L. Cabyova, Z. Bezakova. International Scientific Conference on Marketing Identity 2016: Brands We Love (pp. 284-293). UNIV SS Cyril \& Methodius TrnavaUCM Trnava.

Şahin, E.; Şahin, E. ve Kara, N.S. (2018). Türkiye'de gıda sektöründe faaliyette bulunan markalar üzerine bir etkinlik ve verimlilik analizi. selçuk Üniversitesi. Sosyal Bilimler Meslek Yüksekokulu Dergisi, 21(2), 323-335.

Tezcan, N. (2019). İ̧̧letmelerde finansal performans ve ihracat düzeyi arasındaki ilişki: Türkiye otomotiv sanayi örneği. Çağ Üniversitesi Sosyal Bilimler Dergisi, 16(2), 87-101.

Tunca, M., Ömürbek, N., Cömert, H. \& Aksoy, E. (2016). OPEC ülkelerinin performanslarının çok kriterli karar verme yöntemlerinden entropi ve maut ile değerlendirilmesi. Süleyman Demirel Üniversitesi Vizyoner Dergisi, 7(14), 1-12.

Vatansever, K. (2013). Tedarikçi seçim kararlarında bulanık topsis yönteminin kullanımı ve bir uygulama. Anadolu Üniversitesi Sosyal Bilimler Dergisi, 13(3), 155-168.

Wang T.C. \& Lee H.D. (2009). Developing a fuzzy topsis approach based on subjective weights and objective weights. Expert Systems with Applications, 36, 8980-8985.

Wang, D. H.-M.; Chen, P.-H.; Yu, T. H.-K.; \& Hsiao, C.-Y. (2015). The effects of corporate social responsibility on brand equity and firm performance. Journal of Business Research, 68(11), 2232-2236.

Wang, J. W., Cheng, C. H. \& Cheng, H.K. (2009). Fuzzy hierarchical topsıs for supplier selection. Applied Soft Computing, 9, 377-386.

Wang, T.C. \& Lee, H.D. (2009). Developing a fuzzy topsis approach based on subjective weights and objective weights. Expert Systems With Applications, 36 (5), 8980-8985.

Wood, L. (1998). Brand value: The future. Journal of Brand Management, 5, 245-255.

Yadav, S.K. \& Kapoor, R. (2018). Financial performance ranking of automotive companies in india using topsis method. International Journal of Business Excellence, 16(2), 149-161.

Yanık, L. \& Eren, T. (2017). Borsa İstanbul'da işlem gören otomotiv imalat sektörü firmalarının finansal performanslarının ahp, topsıs, electre ve vıkor yöntemleri ile analizi. Yalova Sosyal Bilimler Dergisi, 8(13), 165-188.

Yazdanparast, A. \&Bayar, O. (2021). Olympic sponsorships and brand value: an empirical analysis. Journal of Advertising, 50(2), 139-159

Zhang, H., Gu, C. L., Gu, L. W. \& Zhang, Y. (2011). The evaluation of tourism destination competitiveness by topsis \& Information entropy-a case in the yangtze river delta of China. Tourism Management, 32(2), 443-451. 